\title{
The Impact of Oceanic Heat Content on the Rapid Intensification of Atlantic Hurricanes
}

\author{
Kevin Law \\ Marshall University \\ United States of America
}

\section{Introduction}

With the increased infrastructure and amount of people living along the United States coastline, it is imperative to improve the accuracy of Atlantic hurricane intensity forecasts. Over the last 10 years, there have been many Atlantic hurricanes, including Hurricanes Katrina and Charley that surprised many forecasters with their rapid intensification and power. The rapid intensification of tropical cyclones is the most serious aspect, when it comes to forecasting. It is generally accepted that sufficient surface ocean temperatures (approximately $26^{\circ} \mathrm{C}$ ) are needed to produce and sustain tropical cyclone formation. However, the sea-surface temperature (SST) has shown not to be critical in intensity forecasting by itself, particularly with rapid intensification (Schade \& Emmanuel, 1999; Law \& Hobgood 2007). Tropical cyclones derive much of their energy from warm, deep ocean water. Therefore, a quantified measure of the amount of this warm, deep water is a better way to measure the amount of energy available to the storm. The oceanic heat content $(\mathrm{OHC})$ is such a variable to measure the amount of warm water available for the tropical cyclone to convert into energy and has been shown to be a much better predictor than SST alone (Zebiak, 1989; McDougall, 2003; Wada \& Usui 2007; Palmer \& Haines, 2009; Shay \& Brewster, 2010).

The accuracy of predicting tropical cyclone tracks currently exceeds the accuracy of intensity prediction. This is largely because track forecasts are largely governed by large-scale processes, such as upper-wind conditions and the positioning of ridges and troughs. These large-scale processes are more easily captured by dynamic numerical models therefore making track forecasts more precise. However, the same dynamic numerical models have difficulty capturing the sub-grid scale features inside of the tropical cyclone. Since the subgrid scale features, such as the temperature/moisture profiles and heat fluxes, tend to govern the intensity of the systems, the dynamic numerical model accuracy of the intensity forecasts lag behind their track counterparts.

While dynamic numerical models tend to lag behind in forecasting intensity, statistical models have been shown to outperform the performance of dynamic models. Many statistical and statistical-dynamic models are used by the National Hurricane Center in Coral Gables, Florida, USA. These would include such models as the Statistical Hurricane Intensity Prediction Scheme or SHIPS and SHIFOR5 which is a 5-day statistical hurricane intensity forecast model. The SHIPS is a statistical-dynamic model uses a variety of dynamic variables such as the maximum sustained surface wind speed, 12-hour intensity change, $850-200 \mathrm{hPa}$ vertical wind shear, the average temperature at $200 \mathrm{hPa}$, and the 850 
hPa relative vorticity (DeMaria \& Kaplan 1999; DeMaria et al., 2005). Many of these climatological and synoptic sub-grid scale variables are averaged over the distance of the storm, to produce intensity forecasts based upon the climatological characteristics of previous tropical cyclones. The SHIFOR5 model uses climatology and persistence as a purely statistical baseline.

Regardless of statistical-dynamic or statistical models, rapid intensification processes still remain to be problematic when it comes to forecasting. The purpose of this paper is to present a statistical-dynamic intensity model that utilizes $\mathrm{OHC}$ and show how critical the variable is to forecast the rapid intensification of Atlantic hurricanes.

\section{Oceanic heat content background}

While the SST may provide the conditions of the sea surface, it does not reveal the conditions of the upper $50 \mathrm{~m}$ of the ocean. Strong relationships have been known to exist between the ocean and tropical cyclone development and intensification (Leipper \& Volgenau, 1972, Shay et al., 2000, Law \& Hobgood, 2007, Maineli et al. 2008). This area is critical to tropical cyclone development and intensification as deep water upwelling provides the warm water necessary to eventually be converted into latent heat energy. The OHC which is sometimes referred to as Tropical Cyclone Heat Potential (TCHP) is defined as the integrated vertical temperature from the sea surface to the depth of the $26^{\circ} \mathrm{C}$ isotherm. The $26^{\circ} \mathrm{C}$ isotherm corresponds to the threshold necessary for tropical cyclone development (Gray 1968). However despite being a key variable, OHC fields cannot be created by hydrographic observations alone. These fields have to be produced from those observations by integrating the temperature profile down to the $26^{\circ} \mathrm{C}$ isotherm. OHC values typically range over $100 \mathrm{~kJ} \mathrm{~cm}^{-2}$ and were found primarily for rapid major tropical cyclone intensification (Law \& Hobgood 2007).

$\mathrm{OHC}$ is calculated globally and daily from estimated altimeter-derived vertical temperature profiles (Shay et al. 2000). There have been three different methods designed to estimate this parameter. The first version was a reduced gravity model, used prior to 2005. This method used three variables (a) SSTs derived from the Tropical Rainfall Measuring Mission (TRMM) Microwave Imager (TMI), (b) altimeter estimates of the $20^{\circ} \mathrm{C}$ isotherm chosen because it represents the thermocline and the upper level flow in the Gulf of Mexico and Atlantic (Goni et al, 1996), and (c) the depth of the $26^{\circ} \mathrm{C}$ isotherm based upon a climatological relationship between the $26^{\circ} \mathrm{C}$ and $20^{\circ} \mathrm{C}$ isotherms.

The second version used from January 2005 to October 2008 was based upon a linear regression model between the depth of the $26^{\circ} \mathrm{C}$ and $28^{\circ} \mathrm{C}$ isotherms acquired from temperature profiles and topography estimated by Archiving, Validation and Interpretation of Satellite Oceanographic (AVISO) data. The $\mathrm{OHC}$ was then computed by integrating the temperature profile from the surface down to the $26^{\circ} \mathrm{C}$ isotherm. The third version used from October 2008 to present provides better agreement with observations in the Gulf of Mexico. It estimates the isotherm depth based upon sea height anomalies from satellite observations.

\section{Statistical and statistical-dynamic intensity models}

Statistical models such as SHIFOR5 and Statistical-Dynamic models such as SHIPS use a variety of synoptic and climatological variables to forecast the short-term intensification change of tropical cyclones. Regression equations are created from the climatological tropical cyclone database using each of these variables. However, statistical models 
primarily have used a single set of regression equations to be used uniformly and throughout the entire life-cycle of a particular tropical cyclone. It has been theorized that different sets of regression equations need to be created because parameters change in importance throughout the storm's life cycle. Law \& Hobgood (2007) first developed such a model by incorporating Discriminant Function Analysis (DFA) with the regression equations. By utilizing a DFA, it could be determined how close the tropical cyclone is to its rapid intensification period (RIP). Therefore a specific set of regression equations could be applied based upon how close the tropical cyclone is to the RIP. This particular study expands upon that method of statistical-dynamic intensification model.

\subsection{Dataset and variables}

The investigation consisted of all tropical cyclones in the Atlantic basin from 2002-2007. There were 96 tropical cyclones including 1 unnamed subtropical storm in 2005 and 1 unnamed system in 2006. A series of 12 variables were gathered for all of the storms in 6-hr intervals (Table 1 ).

\begin{tabular}{|l|l|l|}
\hline Latitude (LAT) & 6-hr Change in Wind Speed $(\Delta \mathrm{WS})$ & $850 \mathrm{hPa}$ Relative Humidity $(\mathrm{RH})$ \\
\hline Longitude (LONG) & 6-hr Change in Pressure $(\Delta \mathrm{P})$ & Sea Surface Temperature (SST) \\
\hline Wind Speed (WS) & $\begin{array}{l}\text { 850-200 hPa Wind Sheer Magnitude } \\
(\text { ShrMag) }\end{array}$ & Inception Time (Incep) \\
\hline Central Pressure (CP) & $\begin{array}{l}\text { 850-200 hPa Wind Shear Direction } \\
\text { (ShrDir) }\end{array}$ & Oceanic Heat Content (OHC) \\
\hline
\end{tabular}

Table 1. List of 12 variables used in the statistical intensity model.

The latitude (LAT), longitude (LONG), wind speed (WS), and central pressure (CP) are available in the Atlantic Best Track dataset from the National Hurricane Center archives. This file contains the 6-hr locational coordinates as well as the maximum sustained winds and the central pressure. The $6-\mathrm{hr}$ changes in wind speed $(\Delta \mathrm{WS})$ and pressure $(\Delta \mathrm{P})$ were easily computed from this dataset. The $850-200 \mathrm{hPa}$ wind sheer magnitude (ShrMag) and direction (ShrDir), $850 \mathrm{hPa}$ relative humidity (RH), and sea surface temperature (SST) were obtained from the National Centers for Environmental Prediction-National Center for Atmospheric Research (NCEP-NCAR) reanalysis dataset (Kalnay et al. 1996). This 6-hourly reanalysis dataset is on a $2.5^{\circ}$ latitude-longitude grid or approximately a $210 \mathrm{~km}$ resolution. To smooth any extremes in the variables, a $10^{\circ}$ latitude-longitude "box" was created and positioned over the storm center indicated by the Best Track dataset. This was to create an average value of the variable over the entire area of the storm.

However, the SST data were available on a weekly time scale on a $1^{\circ}$ latitude-longitude grid. The grid boxes were adjusted to fit the same area used for the relative humidity and the wind shear variables. The SSTs were derived from a variety of in-situ ship and buoy data, satellites, and simulated SSTs for sea ice. Prior to calculating the database, these parameters were adjusted for biases using simulated SSTs described by Reynolds (1988) and Reynolds and Marsico (1993) and more information describing the ocean interaction analysis can be found in Reynolds and Smith (1994).

The Oceanic Heat Content (OHC) was obtained from a database constructed by the Cooperative Institute for Research in the Atmosphere (CIRA) at Colorado State University. This database utilized techniques described by Mainelli et al. (2008) and had the same $1^{\circ}$ latitude-longitude resolution as the SST reanalysis data. These data were similarly averaged over the storm center to give an average OHC over the entire area of the tropical cyclone. 


\subsection{Methodology}

The hypothesis of this study suggests that more than one regression model, rather than just one uniform model, is necessary to accurately forecast hurricane intensity. By using the multiple regression models, it attempts to show the importance of OHC upon rapid hurricane intensification. The statistical-dynamic intensity model used in this study used a variety of multiple regression equations to forecast the 24-hour change in the maximum sustained winds. To form the equations, multiple regression analysis was used from a climatological database that was formed from the 96 tropical cyclones in the sample. This database was created from the all 12 variables listed in Table 1. In total, there were 3348 individual cases.

Every 6-h time interval for each storm was categorized based upon the current intensity of the system: tropical storm, minor hurricane, or major hurricane. Of the 3348 total cases, 2633 were tropical storm status, 445 were minor hurricanes (Category 1 or 2 on the SaffirSimpson Scale), and 270 major hurricanes (Category 3, 4, or 5). In addition, each time interval was divided based upon the future 6 -h intensity change: weakening ( $>5 \mathrm{kts})$, little change $( \pm 5 \mathrm{kts})$, strengthening ( $>5 \mathrm{kts})$. Of the 3348 total cases, 697 exhibited future weakening intensity, 1857 cases showed little change, and 794 exhibited future strengthening characteristics. Therefore there were nine different categories and sets of multiple regression equations to develop. After each was classified, the multiple regression analysis was completed using future 24-hour maximum sustained wind speed change as the dependent variable and the 12 variables listed on Table 1 as the independents. Figure 1 shows a schematic of the combination of regression equations developed.

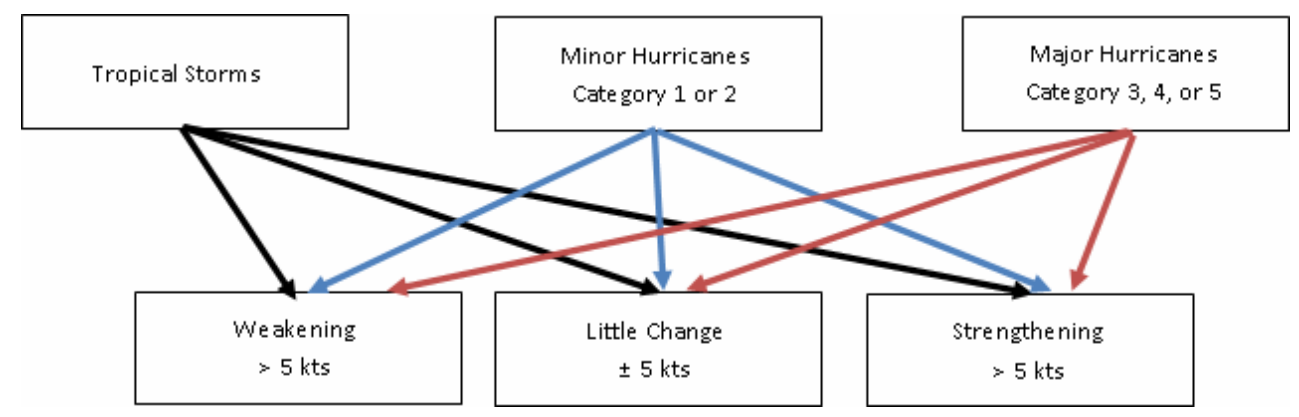

Fig. 1. Schematic of the nine categories of regression equations

When constructing the multiple regression equations and climatology database, the future 6-hour is known. However, when using as a real-time prediction model, obviously the future 6-hour intensity change will not be known and a prediction technique must be used. Based upon the current characteristics of the variables used in the model, the DFA is then used as a prediction method to forecast the future 6-hour intensity change (weakening, little change, strengthening).

The DFA equations were then applied to the same storms in the database to verify their selection accuracy. The most discriminating variables between the 9 categories as well as the most significant variables could be identified. Sample forecasts were created from the regression equations and also applied to the storms in the sample. Mean error statistics were produced so the model could be compared to other statistical models and other official forecasts. 


\subsection{Revisions}

The previous method used by Law and Hobgood (2007) used a two-step DFA. That version was used to predict how close the storm was to its rapid intensification period and then predict the magnitude of the intensification change. The first step of the DFA was used to predict what status the tropical would eventually become (i.e. tropical storm, minor hurricane, or major hurricane). The second step of the DFA was then used to predict how close it was to its RIP (i.e. the 24 -h period where the maximum pressure decrease occurred). However, the problem with this version was that it could not be used over the entire life cycle of the storm.

The method in this study used a one-step DFA approach, since it used the current status of tropical cyclone rather than trying to predict what it "would eventually become". The DFA was only used to predict the 6-h future intensity increase. By predicting this parameter, it could be applied over the entire life cycle of the storm. In addition, the other major revision was the inclusion of $\mathrm{OHC}$ which was not considered in the previous edition.

\section{Regression equations}

As mentioned in Section 3, there were 3348 individual cases. Table 2 shows the number of cases for each of the nine types of regression equations which were created. A stepwisemultiple regression technique was performed to create the nine equations in each category. Variables that were not significant at the $95 \%$ confidence interval were omitted from the equation. For the tropical storm cases, there were 494, 1621, and 518 cases for the future weakening, little change, and future strengthening cases, respectively. For the minor hurricane cases, there were 122, 151, and 172 cases for the future weakening, little change, and future strengthening cases, respectively. Finally, for the major hurricane cases, there were 81,85 , and 104 for the future weakening, little change and future strengthening cases, respectively.

\begin{tabular}{|c|c|c|c|c|}
\hline & $\begin{array}{c}\text { Tropical } \\
\text { Storms }\end{array}$ & $\begin{array}{c}\text { Minor } \\
\text { Hurricanes }\end{array}$ & $\begin{array}{c}\text { Major } \\
\text { Hurricanes }\end{array}$ & \\
\hline Weakening & 494 & 122 & 81 & $\mathbf{6 9 7}$ \\
\hline Little Change & 1621 & 151 & 85 & $\mathbf{1 8 5 7}$ \\
\hline Strengthening & 518 & 172 & 104 & $\mathbf{7 9 4}$ \\
\hline & $\mathbf{2 6 3 3}$ & $\mathbf{4 4 5}$ & $\mathbf{2 7 0}$ & $\mathbf{3 3 4 8}$ \\
\hline
\end{tabular}

Table 2. Number of cases for each of the nine types of regression equations

For all 9 equations, the most significant variable is the closest to the y-intercept and decreases in significance. The first three equations are for tropical storms (Equations 1-3). Equations 1, 2, and 3 are for future weakening, little change, and future strengthening cases, respectively. The next set of equations (Equations 4-6) is for minor hurricanes. Likewise, Equations 4, 5, and 6 are for future weakening, little change and future strengthening cases, respectively. The last set of equations (Equations 7-9) is for major hurricanes. Again, Equations 7, 8, and 9 are for future weakening, little change, and future strengthening cases, respectively.

$$
-.219 \text { SST - } .155 \text { LAT - .075 LONG -.360 WS +75.478 }
$$




$$
\begin{aligned}
& .10 \mathrm{LONG}-.193 \Delta \mathrm{P}+.036 \mathrm{RH}-.054 \text { ShrMag }-.047 \mathrm{WS}+.106 \Delta \mathrm{WS}-.005 \text { Incep }-.090 \\
& -.296 \mathrm{SST}-.146 \mathrm{ShrMag}+.071 \mathrm{LONG}-.178 \mathrm{CP}-.282 \mathrm{LAT}-.834 \Delta \mathrm{CP}+286.731
\end{aligned}
$$

For the tropical storm cases, wind speed, latitude/longitude, pressure, and sea surface temperature were significant variables in predicting the intensification. OHC was not significant for the tropical storms. This suggests that while the storms are weak, it is not necessary to have warm, deep ocean water and that using sea surface temperatures are sufficient.

$$
\begin{gathered}
.338 \text { LAT }-.428 \text { RH }-.512 \Delta \mathrm{CP}-.244 \text { LONG }+9.409 \\
.107 \text { CP }-104.760 \\
-.654 \text { ShrMag - } .072 \text { Incep }+.317 \text { LONG - } .698 \text { LAT + } 33.955
\end{gathered}
$$

Similarly, minor hurricanes did not incorporate OHC. Minor hurricane intensification was strongly dependent upon the location (latitude/longitude), either central pressure or the change in the pressure, relative humidity, and if it happens to ben strengthening vertical wind shear. Like tropical storms, it suggests that perhaps $\mathrm{OHC}$ is not significant when forecasting the intensity of minor hurricanes.

$$
\begin{gathered}
.272 \text { OHC }-1.157 \text { LONG }+35.930 \\
-.325 \text { LAT }+5.981 \\
-.713 \text { ShrMag }-.133 \text { OHC }-.094 \text { Incep }+.643 \text { LONG }+1.860
\end{gathered}
$$

However, with major hurricanes $\mathrm{OHC}$ was a very influential variable. In both the weakening and strengthening cases $\mathrm{OHC}$ was significant. Latitude and longitude were significant as well as vertical wind shear in strengthening cases. Since OHC was significant rather than SST, it suggested that warm, deep ocean water is important and OHC better represents this parameter.

\section{Discriminant function analysis classifications}

The DFA was run on each of the three categories (tropical storms, minor hurricanes, and major hurricanes). This was performed to analyze which variables are the most significant in differentiating between groups. The standardized discriminant function coefficients were determined and are listed in Tables 3, 4, and 5 (tropical storms, minor hurricanes, and major hurricanes, respectively. These tables show the relative significance of each variable to discriminate among each group.

$\mathrm{OHC}$ was $10^{\text {th }}$ (Table 3 ) and SST was $3^{\text {rd }}$ showing that SST was more important than OHC when discriminating among tropical storms. Tropical cyclones that tend to remain weak are influenced by smaller changes in central pressure and wind speed. Since tropical storms are relatively weak, they do not have deep water upwelling and therefore are not influenced as much by $\mathrm{OHC}$.

However, with minor and major hurricanes (Tables 4 and 5) OHC was more significant than SST. For minor hurricanes (Table 4), OHC was $5^{\text {th }}$ on the list while SST was $11^{\text {th }}$. Wind 


\begin{tabular}{|c|c|}
\hline VARIABLE & COEFFICIENT \\
\hline Wind Speed & 0.999 \\
\hline $\begin{array}{c}\text { 6-h Change in Central } \\
\text { Pressure }\end{array}$ & 0.377 \\
\hline Sea Surface Temperature & -0.327 \\
\hline 6-h Change in Wind Speed & -0.281 \\
\hline Central Pressure & 0.279 \\
\hline Longitude & 0.226 \\
\hline Wind Shear Magnitude & 0.153 \\
\hline Latitude & 0.121 \\
\hline Inception Time & 0.065 \\
\hline Oceanic Heat Content & -0.023 \\
\hline Relative Humidity & 0.018 \\
\hline Wind Shear Direction & 0.004 \\
\hline
\end{tabular}

Table 3. Standardized discriminant function coefficients for tropical storms

shear, latitude, pressure, and wind speed were the most significant but since OHC was more significant than SST, it suggests that deep ocean water becomes more important for these stronger systems. Likewise, the most significant variables for major hurricanes were wind speed, pressure and latitude (Table 5). OHC was again $5^{\text {th }}$ on the list, while SST was $8^{\text {th }}$ in significance suggesting that deep, water upwelling occurs and $\mathrm{OHC}$ indeed captures this parameter better than SST. Another interesting facet was that wind shear magnitude was the most important for minor hurricanes but noticeably lower for major hurricanes. Since major hurricanes exhibit little, if any, vertical wind shear, perhaps this explains the lower significance. On the other hand, minor hurricanes may be experiencing a larger magnitude of wind shear, which is what is preventing it from becoming a major hurricane.

\section{Results}

\subsection{Classification accuracy and mean values}

After the DFA was run and significant variables were found, the DFA was then applied to all 3348 cases to examine the accuracy. The overall classification accuracy for tropical storms was 55.4\%. Assuming there was an equal possibility of each of nine scenarios, the DFA added skill to the selection (e.g. $55.4 \%$ versus $11.1 \%$ ). Tropical storm (Table 6) weakening cases were classified correctly $69.2 \%$ of the time while little change and strengthening cases were accurately classified $45.3 \%$ and $65.1 \%$, respectively. Minor hurricane overall classification accuracy was $59.3 \%$. The weakening cases for minor hurricanes were correctly classified $51.9 \%$, little change $49.1 \%$, and strengthening cases $77.4 \%$ (Table 7). Overall major hurricane overall accuracy was $68.1 \%$. The weakening cases for major hurricanes were correctly classified $72.5 \%$, little change $60.3 \%$, and strengthening cases $68.0 \%$ (Table 8 ). Since the classification accuracy of major hurricanes was better than tropical storms and minor hurricanes, it suggests that the characteristics of major hurricanes are more discriminating. $\mathrm{OHC}$ was one of these key discriminating variables (Table 5) and plays a significant role in determining whether major hurricanes will weaken or strengthen. 


\begin{tabular}{|c|c|}
\hline VARIABLE & COEFFICIENTS \\
\hline Wind Shear Magnitude & 0.631 \\
\hline Latitude & 0.429 \\
\hline Central Pressure & 0.392 \\
\hline Wind Speed & 0.296 \\
\hline Oceanic Heat Content & -0.270 \\
\hline 6-h Change in Wind \\
Speed & -0.249 \\
\hline Longitude & 0.240 \\
\hline Inception Time & 0.165 \\
\hline 6-h Change in Pressure & 0.122 \\
\hline Relative Humidity & -0.117 \\
\hline Sea Surface Temperature & 0.053 \\
\hline Wind Shear Direction & -0.045 \\
\hline
\end{tabular}

Table 4. Standardized discriminant function coefficients for minor hurricanes

\begin{tabular}{|c|c|}
\hline VARIABLE & COEFFICIENTS \\
\hline Wind Speed & 1.107 \\
\hline Central Pressure & 0.621 \\
\hline Longitude & 0.607 \\
\hline Latitude & 0.586 \\
\hline 6-h Change in Wind \\
Speed & -0.572 \\
\hline 6-h Change in Pressure & -0.357 \\
\hline Oceanic Heat Content & -0.346 \\
\hline Relative Humidity & 0.307 \\
\hline Wind Shear Magnitude & 0.268 \\
\hline Sea Surface Temperature & 0.059 \\
\hline Wind Shear Direction & -0.025 \\
\hline Inception Time & -0.007 \\
\hline
\end{tabular}

Table 5. Standardized discriminant function coefficients for major hurricanes

However, OHC was not a key discriminating variable for tropical storms and minor hurricanes. It is widely known that as the strength of the hurricane increases, warmer SSTs are necessary to support it as the amount of energy extracted from the ocean increases (Anthes \& Chang, 1978). Conversely, there is an inverse relationship between vertical wind shear and hurricane intensity. Table 9 shows the mean $\mathrm{OHC}$ and wind shear for all 3348 cases and the different categories of tropical cyclones. The mean values for $\mathrm{OHC}$ and wind shear were $27.0 \mathrm{~kJ} \mathrm{~cm}^{-2}$ and $12.3 \mathrm{~m} \mathrm{~s}^{-1}$ for tropical storms. OHC slightly decreased and wind shear increased slightly however for Category 1 hurricanes. Then as the hurricane intensity increased, the OHC increased and wind shear decreased as expected. There was a noticeable increase in $\mathrm{OHC}$ from Category 3 to Category 4, where it increased from $45.0 \mathrm{~kJ}$ $\mathrm{cm}^{-2}$ to $66.0 \mathrm{~kJ} \mathrm{~cm}^{-2}$. Similarly another large increase took place from Category 4 to Category $5\left(66.0 \mathrm{~kJ} \mathrm{~cm}^{-2}\right.$ to $\left.81 \mathrm{~kJ} \mathrm{~cm}^{-2}\right)$. The large $\mathrm{OHC}$ values of major hurricanes (Category 3, 4, and 5) were dramatically different from the tropical storms and minor hurricanes. This helps 
explain why $\mathrm{OHC}$ was a key discriminator for major hurricanes but was not as significant for tropical storms and minor hurricanes.

\begin{tabular}{|l|l|l|l|}
\hline \multicolumn{1}{|c|}{ Observed } & \multicolumn{3}{|c|}{ Predicted Group } \\
\hline & Weakening (\%) & Little Change (\%) & Strengthening (\%) \\
\hline Weakening & $\mathbf{6 9 . 2}$ & 14.4 & 16.4 \\
\hline Little Change & 20.7 & $\mathbf{4 5 . 3}$ & 34.0 \\
\hline Strengthening & 11.2 & 23.7 & $\mathbf{6 5 . 1}$ \\
\hline
\end{tabular}

Table 6. Classification table showing \% classification for tropical storms

\begin{tabular}{|c|c|c|c|}
\hline Observed & \multicolumn{3}{|c|}{ Predicted Group } \\
\hline & Weakening (\%) & Little Change (\%) & $\begin{array}{c}\text { Strengthening } \\
(\%)\end{array}$ \\
\hline Weakening & $\mathbf{5 1 . 9}$ & 30.5 & 17.6 \\
\hline Little Change & 34.0 & $\mathbf{4 9 . 1}$ & 17.0 \\
\hline Strengthening & 5.8 & 16.8 & $\mathbf{7 7 . 4}$ \\
\hline
\end{tabular}

Table 7. Classification table showing \% classification for minor hurricanes

\begin{tabular}{|c|c|c|c|}
\hline Observed & \multicolumn{3}{|c|}{ Predicted Group } \\
\hline & Weakening (\%) & Little Change (\%) & Strengthening (\%) \\
\hline Weakening & $\mathbf{7 2 . 5}$ & 16.9 & 10.6 \\
\hline Little Change & 14.1 & $\mathbf{6 0 . 3}$ & 25.6 \\
\hline Strengthening & 8.0 & 24.0 & $\mathbf{6 8 . 0}$ \\
\hline
\end{tabular}

Table 8. Classification table showing \% classification for major hurricanes

\begin{tabular}{|l|l|l|}
\hline & Mean OHC (kJ cm-2) & Mean Wind Shear (m s-1) \\
\hline Tropical Storm & 27.0 & 12.3 \\
\hline Category 1 & 24.0 & 12.9 \\
\hline Category 2 & 40.0 & 10.4 \\
\hline Category 3 & 45.0 & 9.2 \\
\hline Category 4 & 66.0 & 8.0 \\
\hline Category 5 & 81.0 & 6.1 \\
\hline
\end{tabular}

Table 9. Mean OHC and Wind Shear for different categories of tropical cyclones

\subsection{Oceanic heat content case studies}

Two of the most powerful, infamous hurricanes that rapidly intensified were Hurricanes Ivan (2004) and Katrina (2005). Both hurricanes achieved Category 5 status and underwent a considerable Rapid Intensification Period (RIP). The OHC was extraordinarily high for both events and both hurricanes traveled over the regions of the highest OHC. Figures 2-9 show maps of the OHC for Hurricane Katrina. On Aug. 23, 2005 (Figure 2), Katrina was tropical storm status and located near the Bahamas (Green dot). The OHC near the center of the storm was $78 \mathrm{~kJ} \mathrm{~cm}^{-2}$, which was much higher than usual for tropical storms. It was natural to expect Katrina to intensify considering the conditions. On Aug. 24, 2005 (Figure 3), Katrina moved toward the northwest over slightly warmer water $\left(99 \mathrm{~kJ} \mathrm{~cm}^{-2}\right)$ while 
maximum sustained winds increased from 30 to $40 \mathrm{kts}$ and the pressure dropped from 1008 $\mathrm{hPa}$ to $1003 \mathrm{hPa}$. By the 25 near high OHC $\left(104 \mathrm{~kJ} \mathrm{~cm}^{-2}\right)$, and was near hurricane status with winds of $60 \mathrm{kts}$. But on the $26^{\text {th }}$ (Figure 5), Katrina passed over the Everglades in Florida and then into the Gulf where slightly cooler waters existed. The OHC dropped to $55 \mathrm{~kJ} \mathrm{~cm}^{-2}$, nevertheless Katrina still intensified and achieved Category 1 hurricane status due to the nearby extraordinarily high $\mathrm{OHC}$. By the 27th (Figure 6), Katrina was beginning to enter the warm core ring in the Gulf of Mexico. The $\mathrm{OHC}$ increased again to $88 \mathrm{~kJ} \mathrm{~cm}^{-2}$ and winds speeds were $100 \mathrm{kts}$ achieving major hurricane (Category 3) status. Over the next 24 hours (Figure 7), Katrina would undergo rapid intensification as it entered the center of the warm core ring with $\mathrm{OHC}$ values of $123 \mathrm{~kJ} \mathrm{~cm}^{-2}$. Maximum sustained winds were $150 \mathrm{kts}$ and was a very strong Category 5 hurricane. It was not until Katrina exited the warm core ring where much lower $\mathrm{OHC}$ existed that the intensity lowered and the eventual landfall near New Orleans, Louisiana to further dissipate (Figures 8 - 10).

Hurricane Ivan started much farther to the east near the African coast (green dot) on Sep. 2, 2004. This area typically has much lower $\mathrm{OHC}$ as indicated by the value of $21 \mathrm{~kJ} \mathrm{~cm}^{-2}$ (Figure 11). As Ivan progressed to the west, winds gradually increased to tropical storm status, but the $\mathrm{OHC}$ was still rather low $\left(22 \mathrm{~kJ} \mathrm{~cm}^{-2}\right)$ (Figure 12). The relatively low $\mathrm{OHC}$ was part of the reason Ivan was slow to initially intensify through the $4^{\text {th }}$ (Figure 13). Over the next 24 hours (Figure 14), Ivan underwent the first rapid intensification period as winds suddenly increased to $110 \mathrm{kts}$ (Category 3) and the $\mathrm{OHC}$ increased to $52 \mathrm{~kJ} \mathrm{~cm}^{-2}$. The winds would gradually decrease as Ivan continued toward the west in the Caribbean on the $6^{\text {th }}$ (Figure 15) despite high OHC values. This temporary weakening was likely due to an eyewall replacement cycle as it would soon start to re-intensify. Over the next 4 days, Ivan was over relatively high $\mathrm{OHC}$ ranging from $58 \mathrm{~kJ} \mathrm{~cm}^{-2}$ to $91 \mathrm{~kJ} \mathrm{~cm}^{-2}$ (Figures 16 - 19) as the winds would approach Category 4 status. Then on Sep. 11 th (Figure 20), Ivan was located just south of Cuba and underwent a second rapid intensification. Ivan entered extremely high $\mathrm{OHC}$ values of $127 \mathrm{~kJ} \mathrm{~cm}^{-2}$ with Category 5 maximum sustained winds of $145 \mathrm{kts}$. The OHC remained extremely high near Ivan over the 12th and 13th (Figures 21 and 22) which would help maintain the intensity at 130 and $140 \mathrm{kts}$, respectively. Subsequently on the $14^{\text {th }}$, Ivan exited the high area of $\mathrm{OHC}$ into a much cooler area with values of $47 \mathrm{~kJ} \mathrm{~cm}^{-2}$ (Figure 23). As a result the maximum sustained winds gradually decreased to $120 \mathrm{kts}$. Ivan passed over a small warm core ring in the central Gulf of Mexico on the 15th (Figure 24) and the $\mathrm{OHC}$ of $96 \mathrm{~kJ} \mathrm{~cm}^{-2}$ allowed the winds to maintain major hurricane status. Hurricane Ivan would ultimately exit the warm core ring making landfall along the Gulf Coast dissipating rapidly on the $16^{\text {th }}$ (Figure 25$)$.

\subsection{Average error}

The regression equations to forecast the 24 hour maximum wind speeds were applied to selected powerful major hurricanes during the 2004-2005 seasons. Based upon the DFA classification, the appropriate regression was applied to forecast the wind speed. The average error for the entire storm track forecast was computed for these tropical cyclones and then compared with the National Hurricane Center 24-h official forecast and another statistical model SHIFOR5 (Table 10) (Franklin 2005; Franklin 2006). The statistical model exhibited in this study exhibited lower error than SHIFOR5 for all seven selected major 


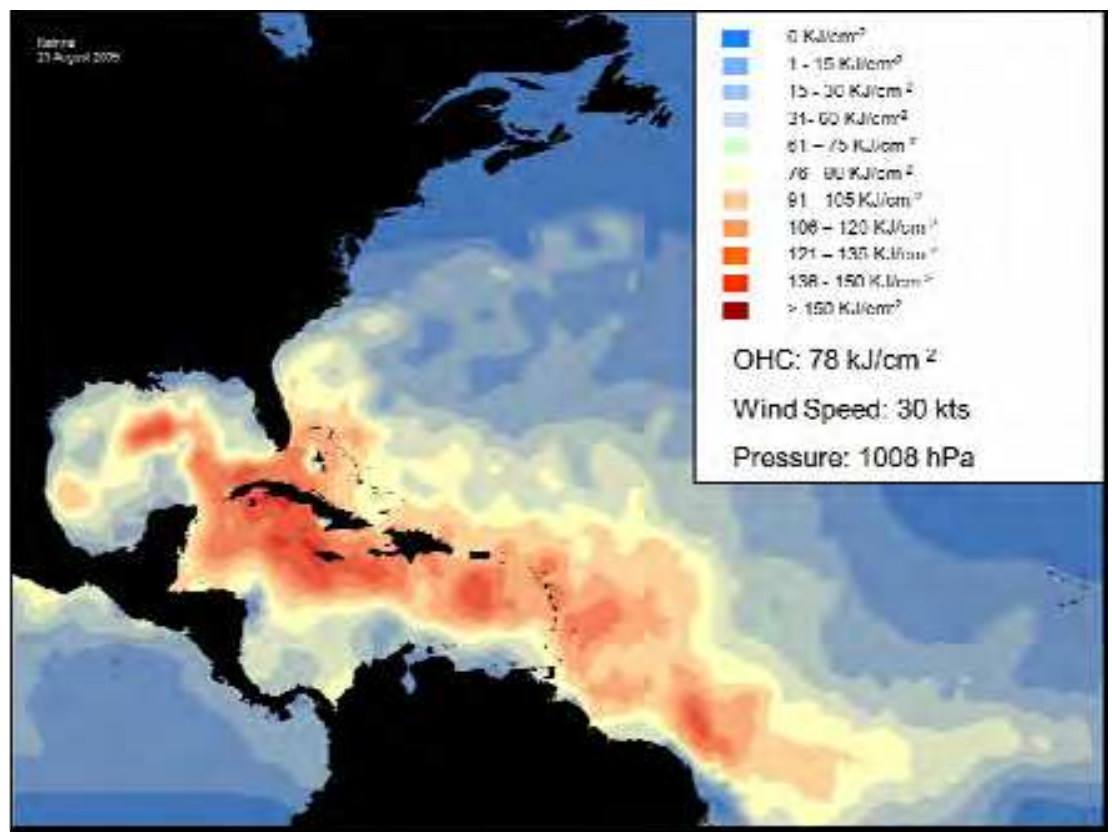

Fig. 2. Oceanic Heat Content of Hurricane Katrina, August 23, 2005 at 1800 UTC.

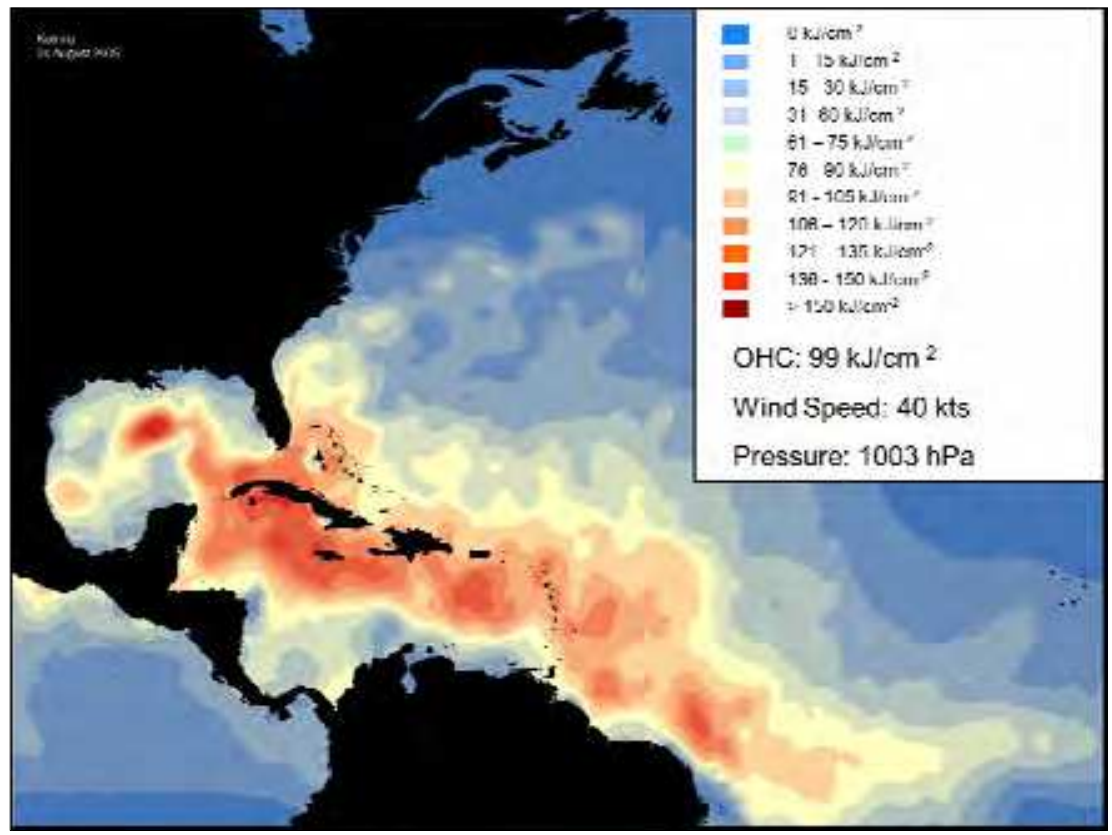

Fig. 3. Oceanic Heat Content of Hurricane Katrina, August 24, 2005 at 1800 UTC. 


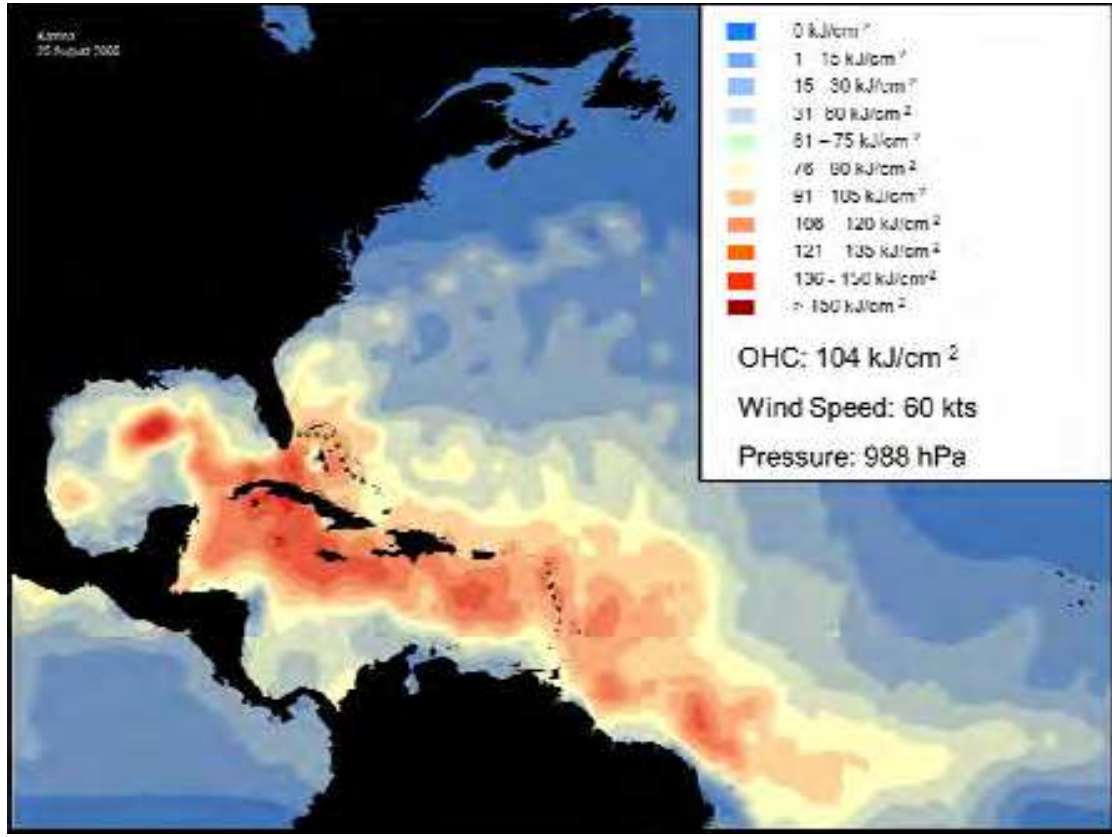

Fig. 4. Oceanic Heat Content of Hurricane Katrina, August 25, 2005 at 1800 UTC.

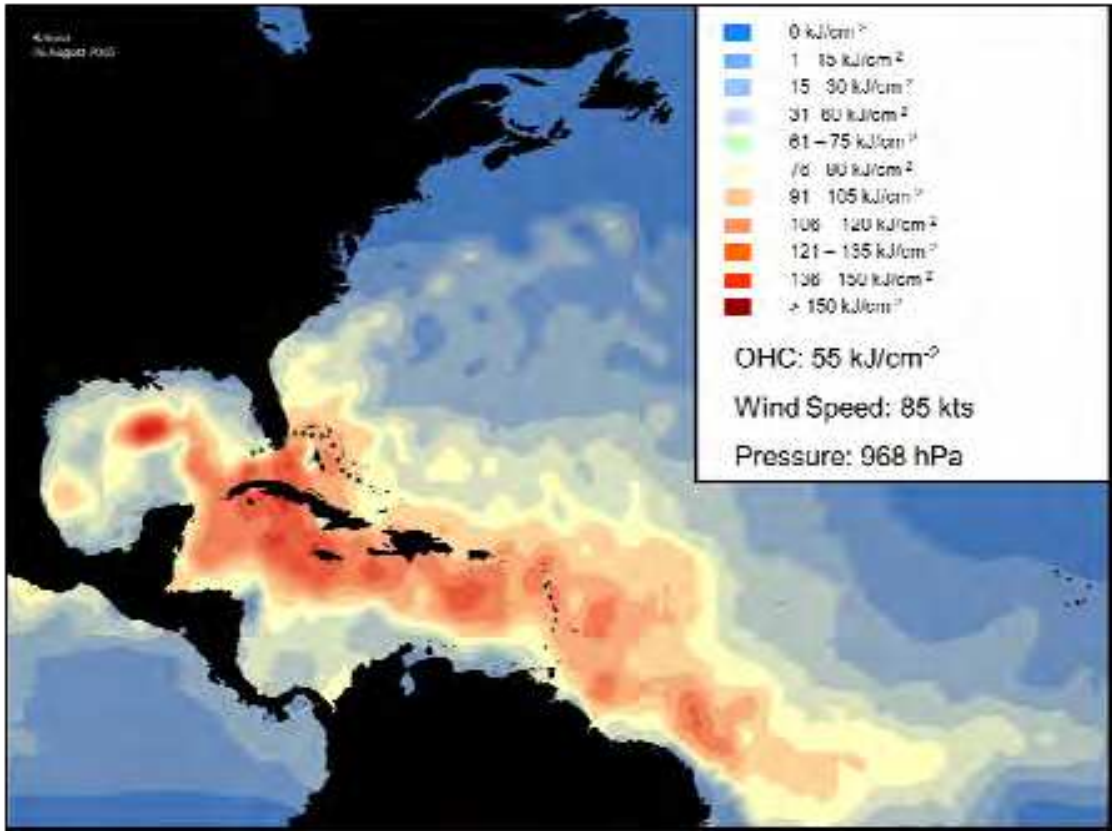

Fig. 5. Oceanic Heat Content of Hurricane Katrina, August 26, 2005 at 1800 UTC. 


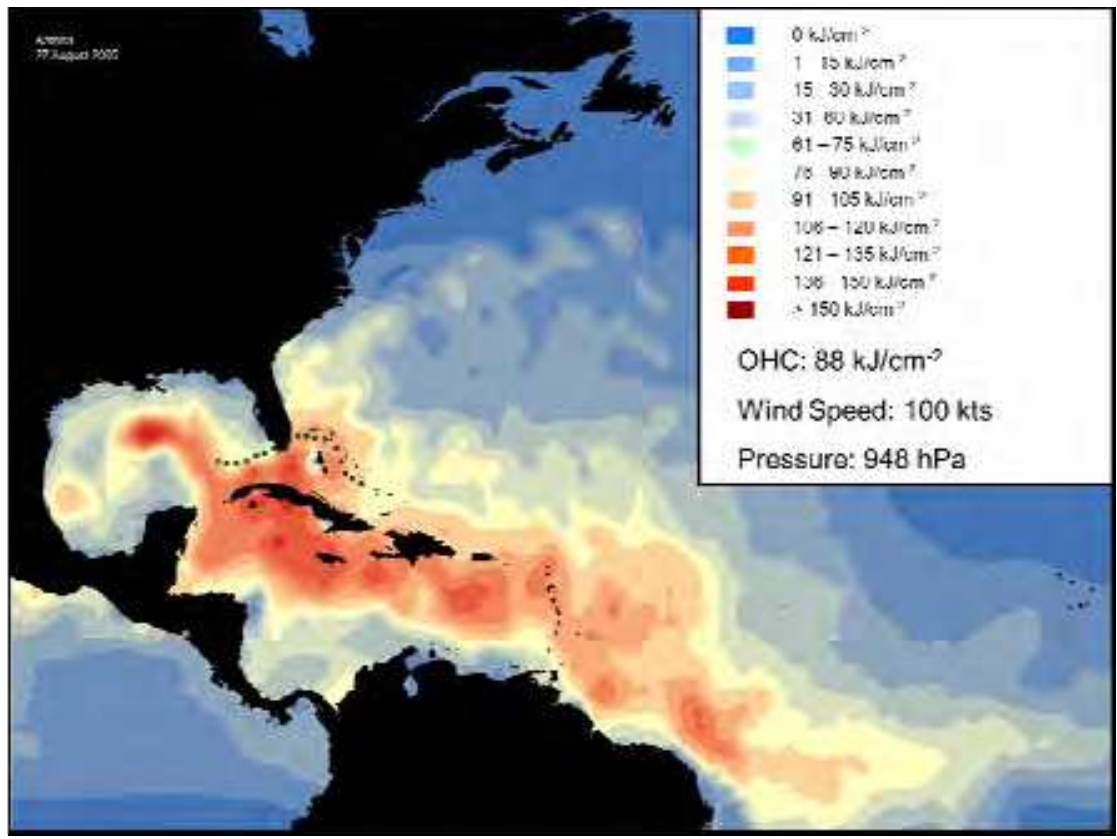

Fig. 6. Oceanic Heat Content of Hurricane Katrina, August 27, 2005 at 1800 UTC.

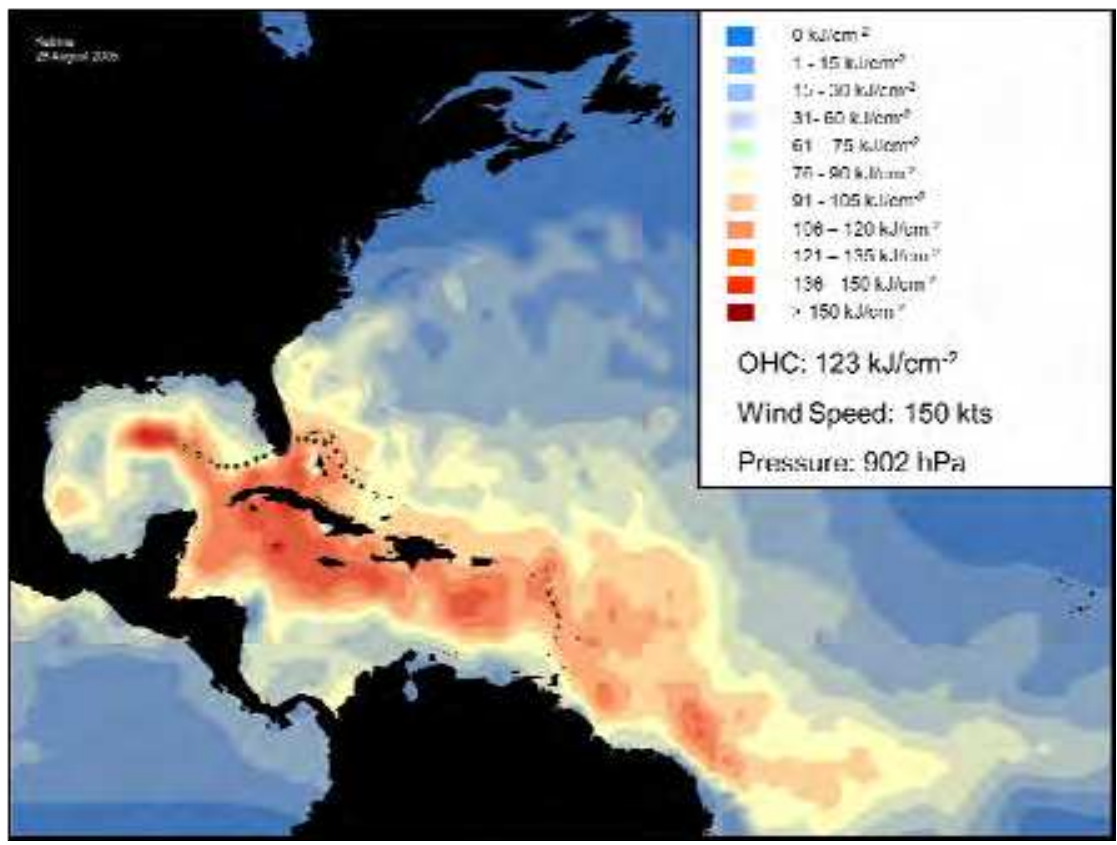

Fig. 7. Oceanic Heat Content of Hurricane Katrina, August 28, 2005 at 1800 UTC. 


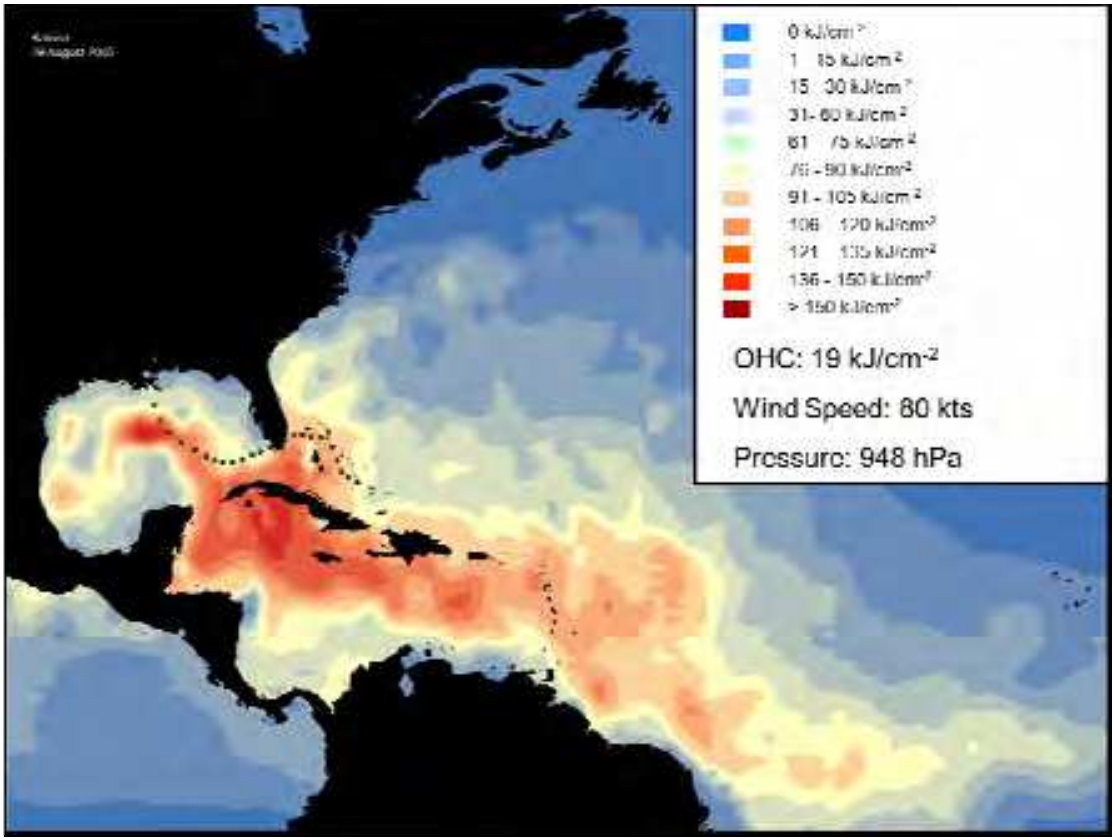

Fig. 8. Oceanic Heat Content of Hurricane Katrina, August 29, 2005 at 1800 UTC.

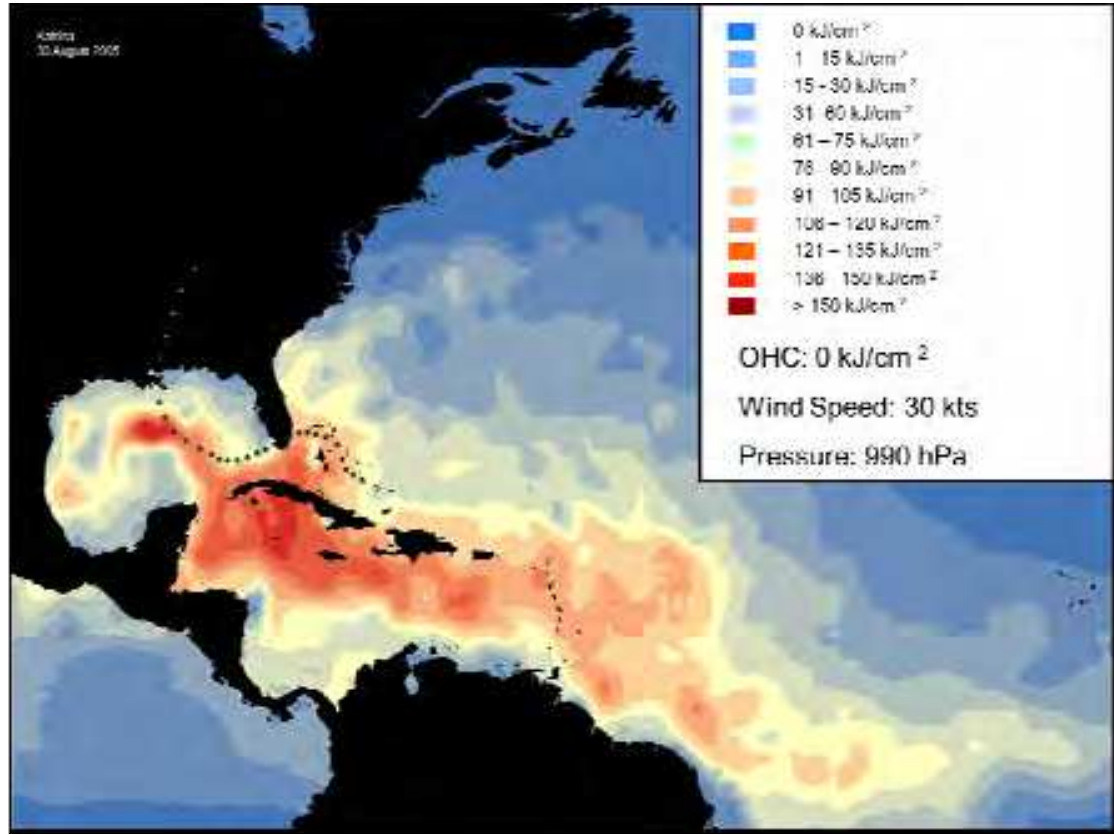

Fig. 9. Oceanic Heat Content of Hurricane Katrina, August 30, 2005 at 1800 UTC. 


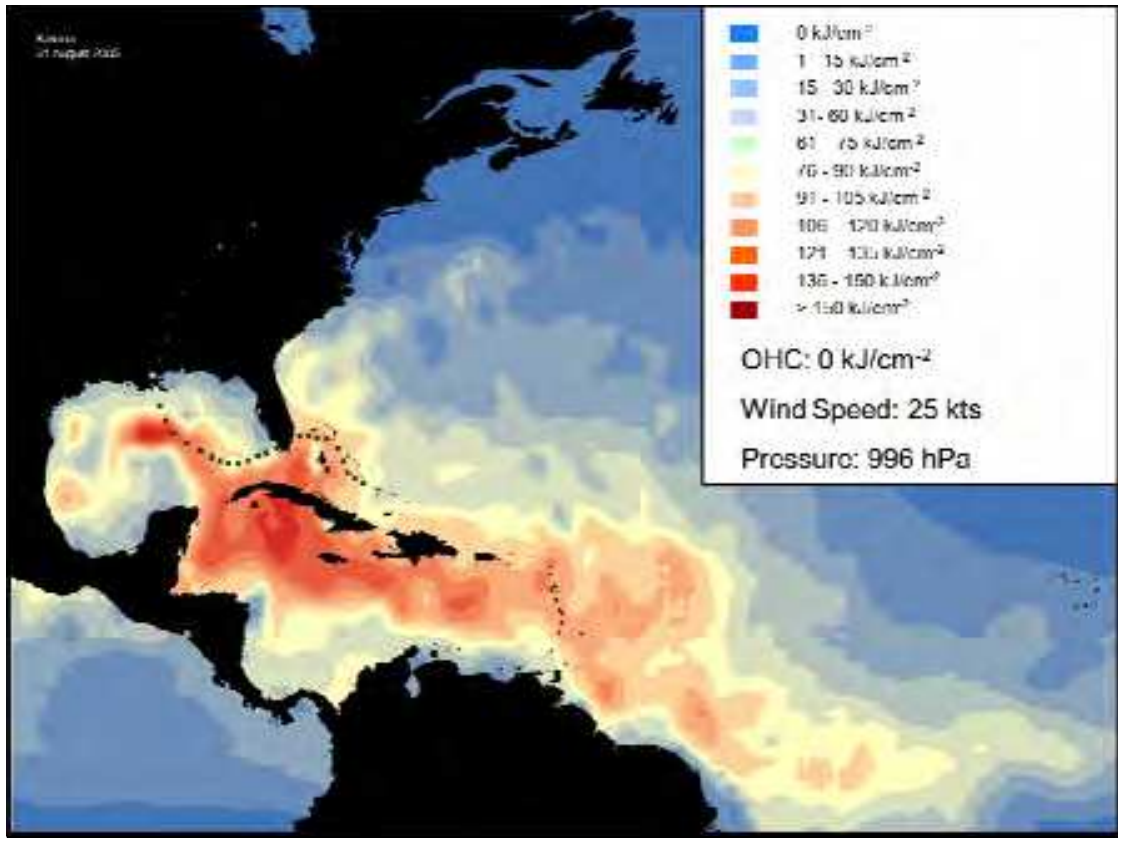

Fig. 10. Oceanic Heat Content of Hurricane Katrina, August 31, 2005 at 1800 UTC.

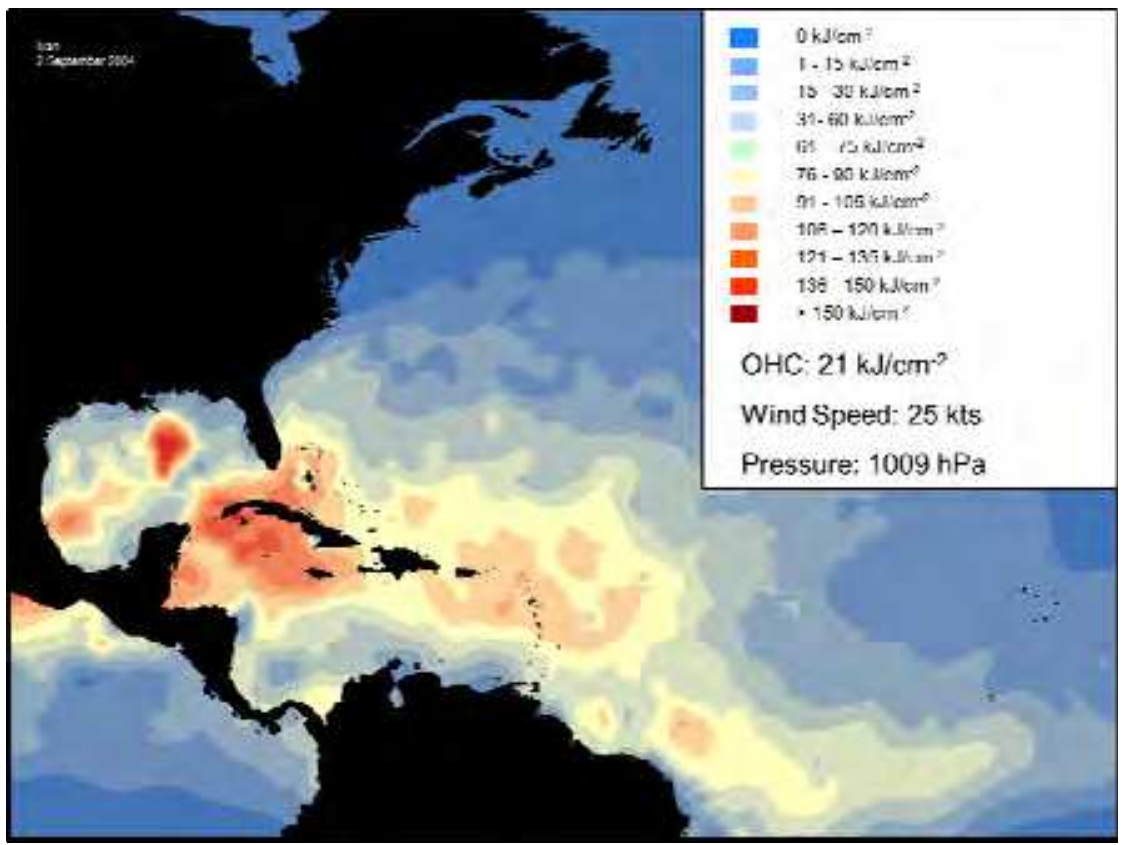

Fig. 11. Oceanic Heat Content of Hurricane Ivan, September 2, 2005 at 1800 UTC. 


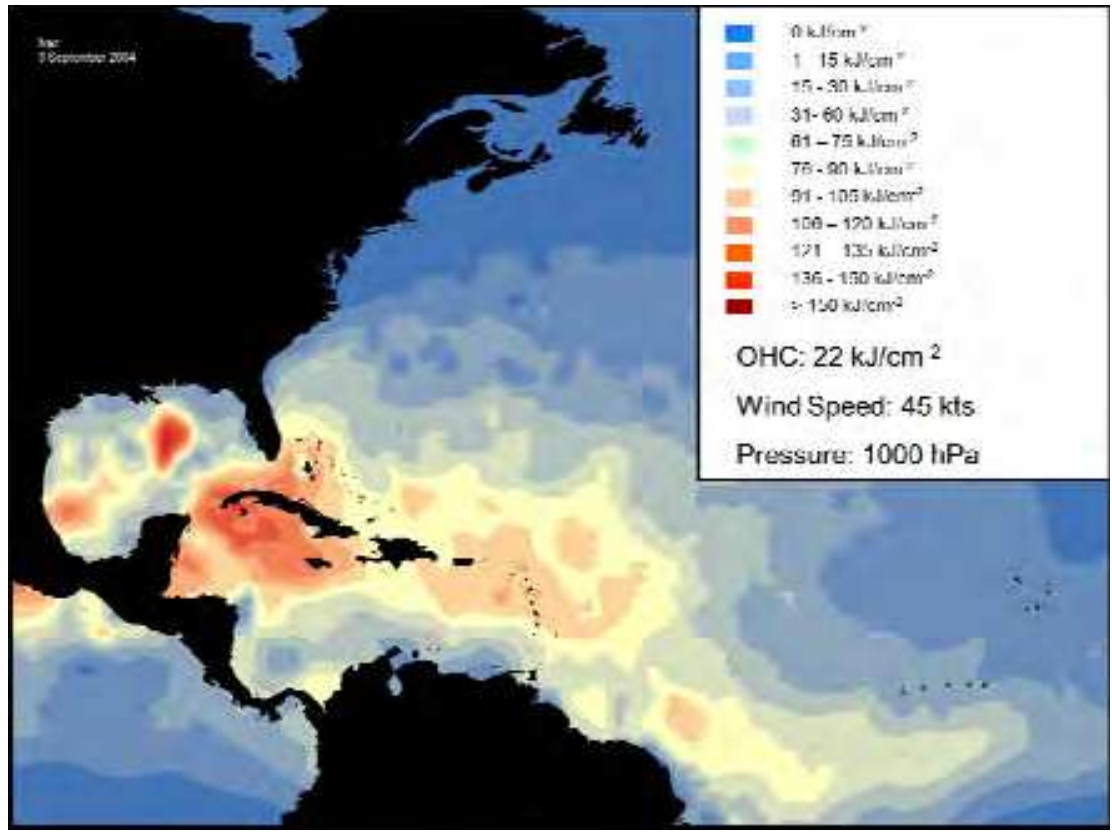

Fig. 12. Oceanic Heat Content of Hurricane Ivan, September 3, 2005 at 1800 UTC.

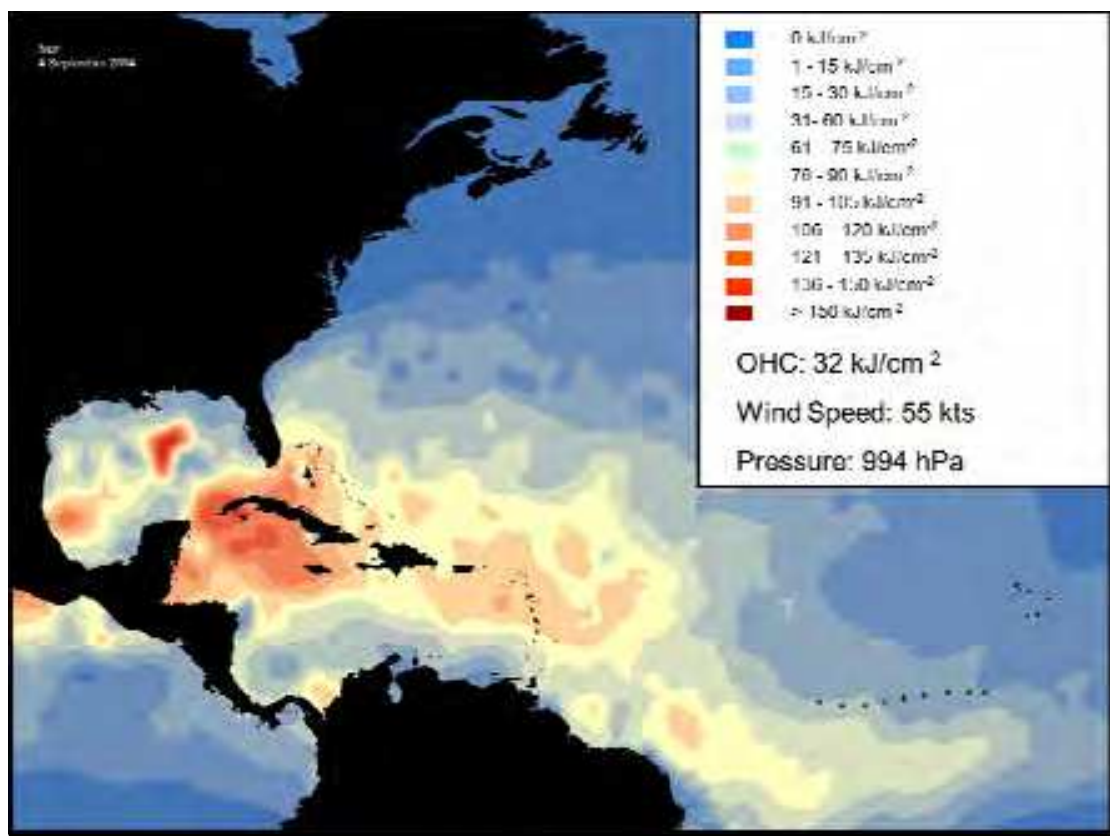

Fig. 13. Oceanic Heat Content of Hurricane Ivan, September 4, 2005 at 1800 UTC. 


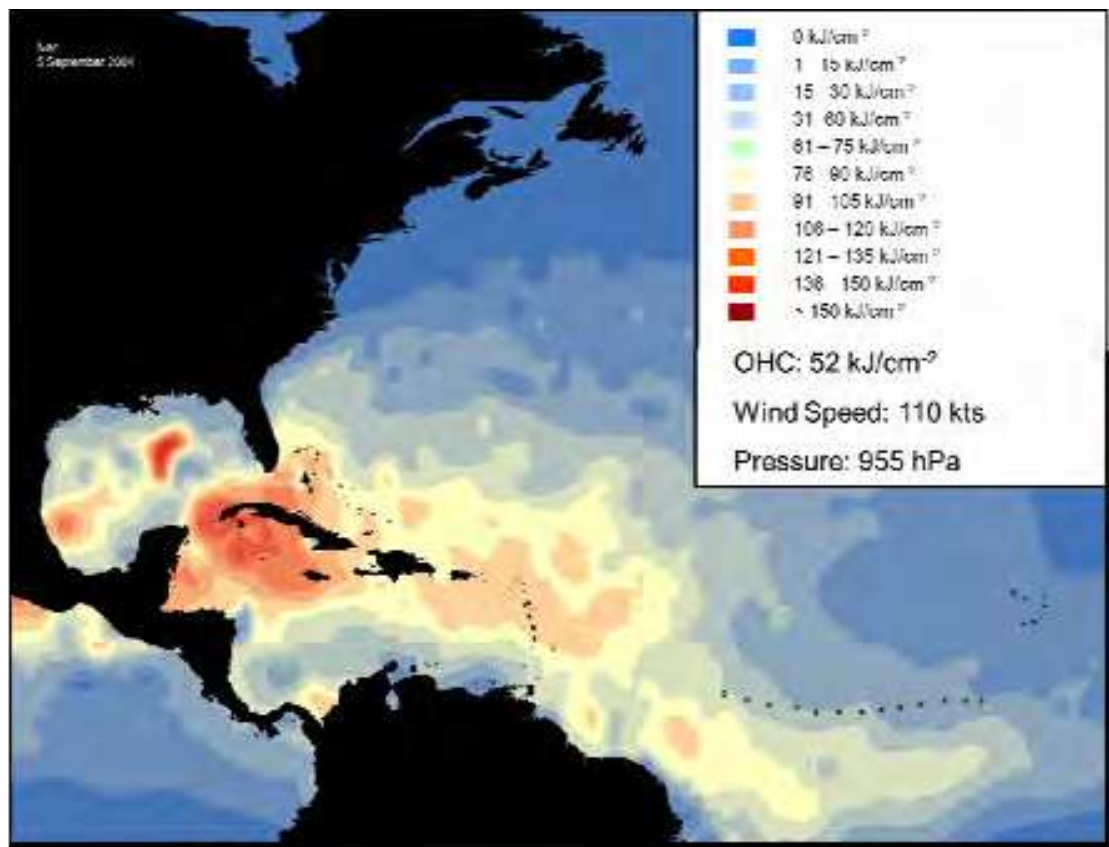

Fig. 14. Oceanic Heat Content of Hurricane Ivan, September 5, 2005 at 1800 UTC.

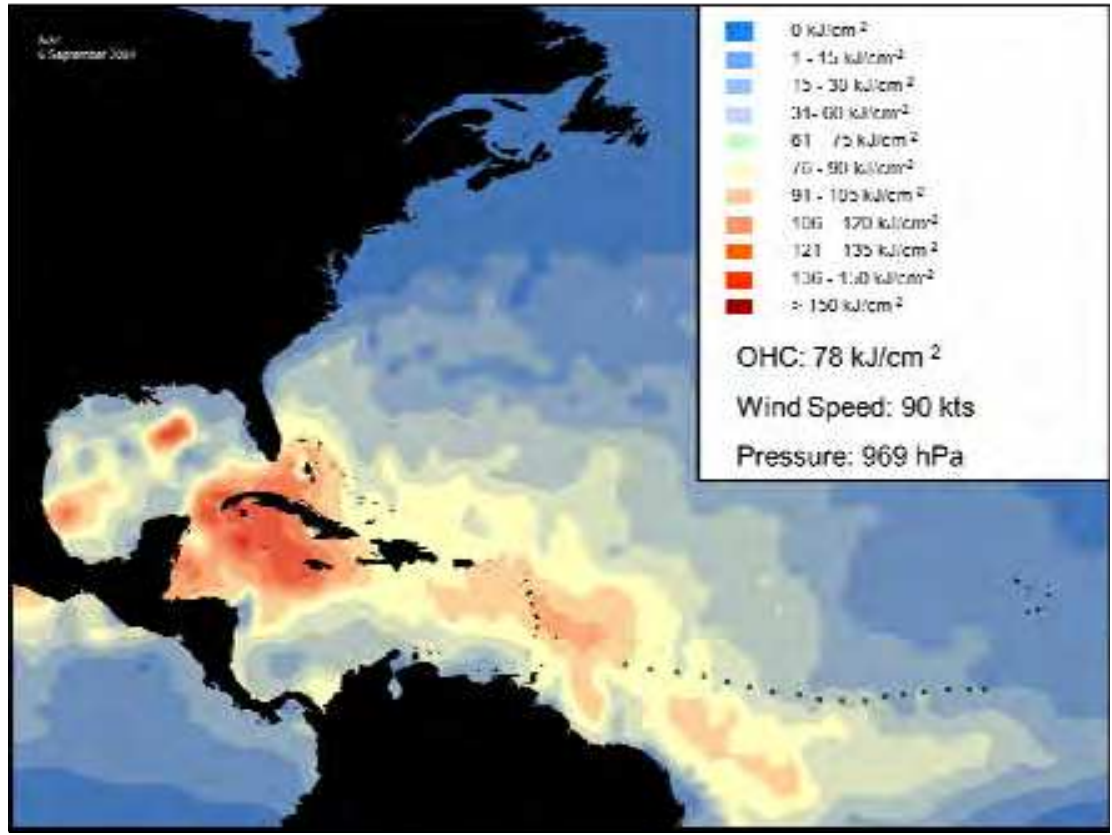

Fig. 15. Oceanic Heat Content of Hurricane Ivan, September 6, 2005 at 1800 UTC. 


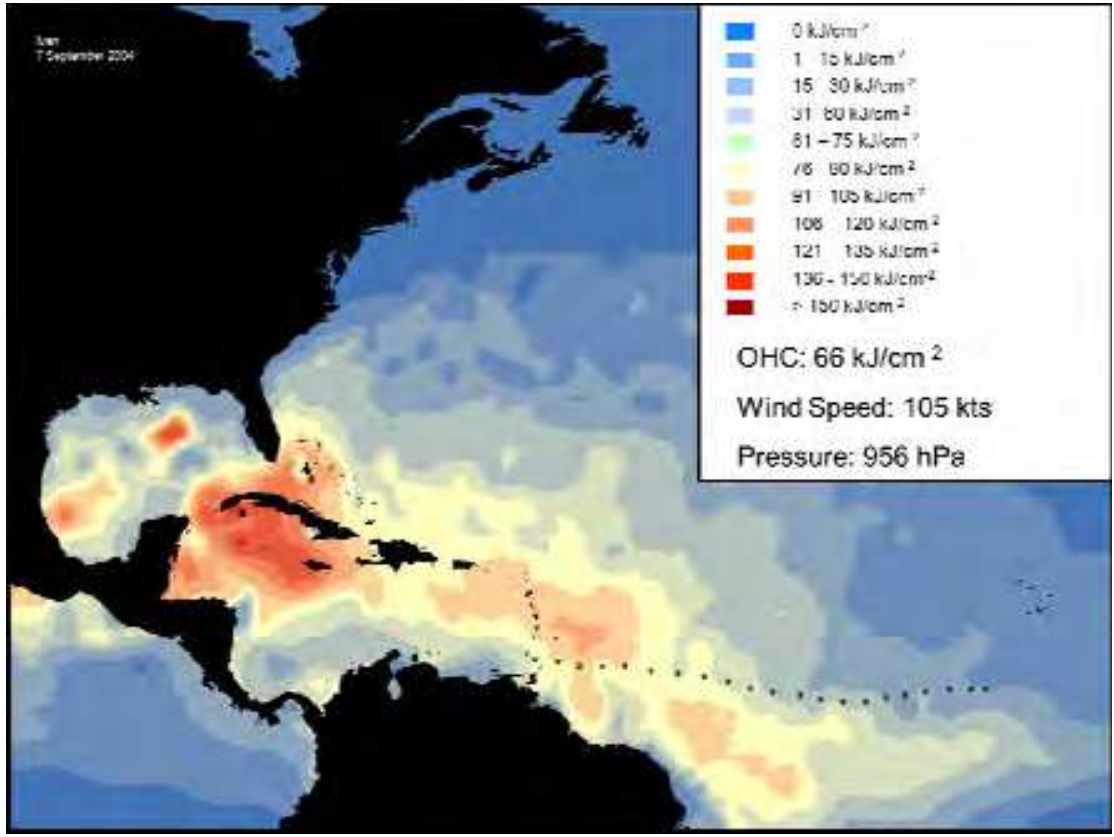

Fig. 16. Oceanic Heat Content of Hurricane Ivan, September 7, 2005 at 1800 UTC.

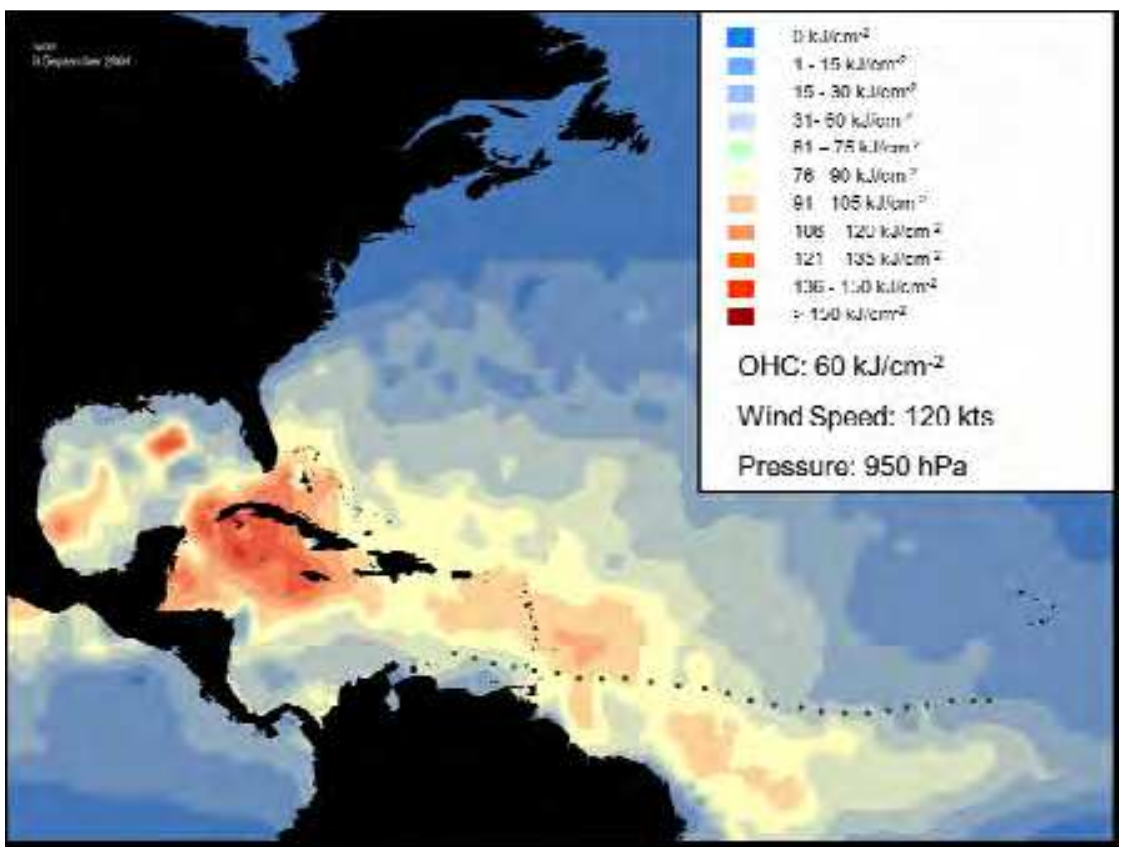

Fig. 17. Oceanic Heat Content of Hurricane Ivan, September 8, 2005 at 1800 UTC. 


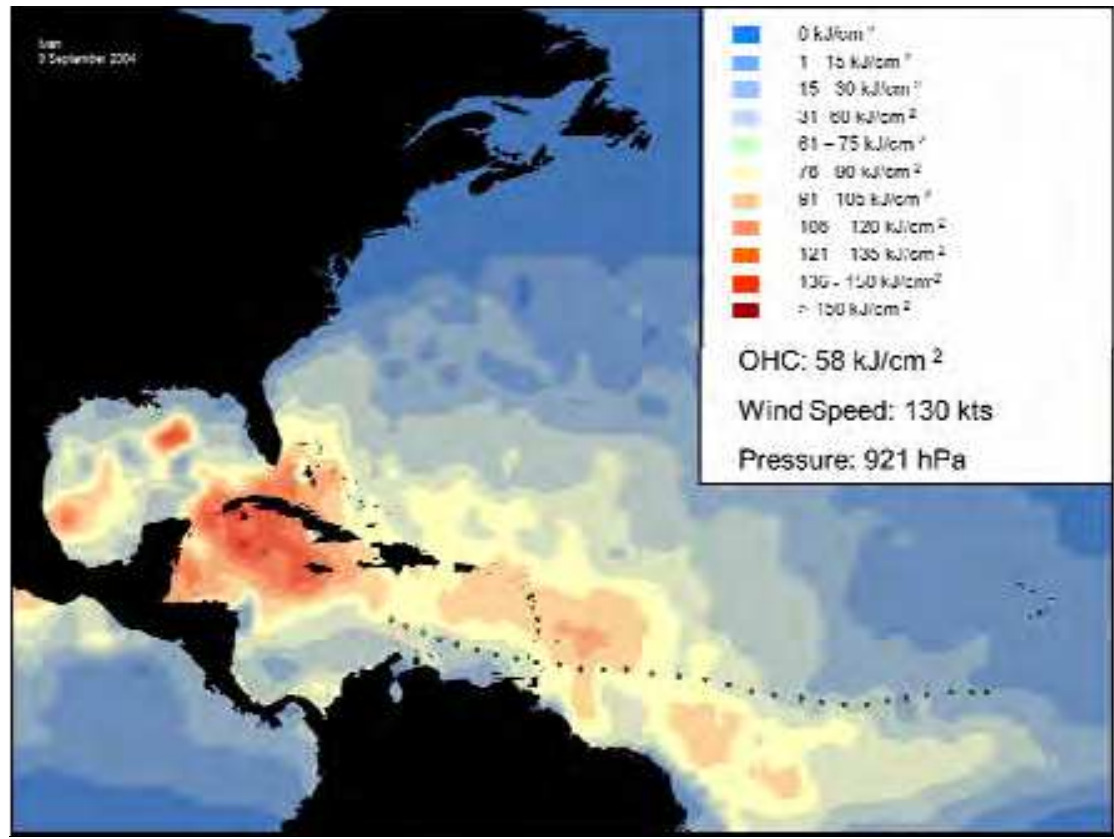

Fig. 18. Oceanic Heat Content of Hurricane Ivan, September 9, 2005 at 1800 UTC.

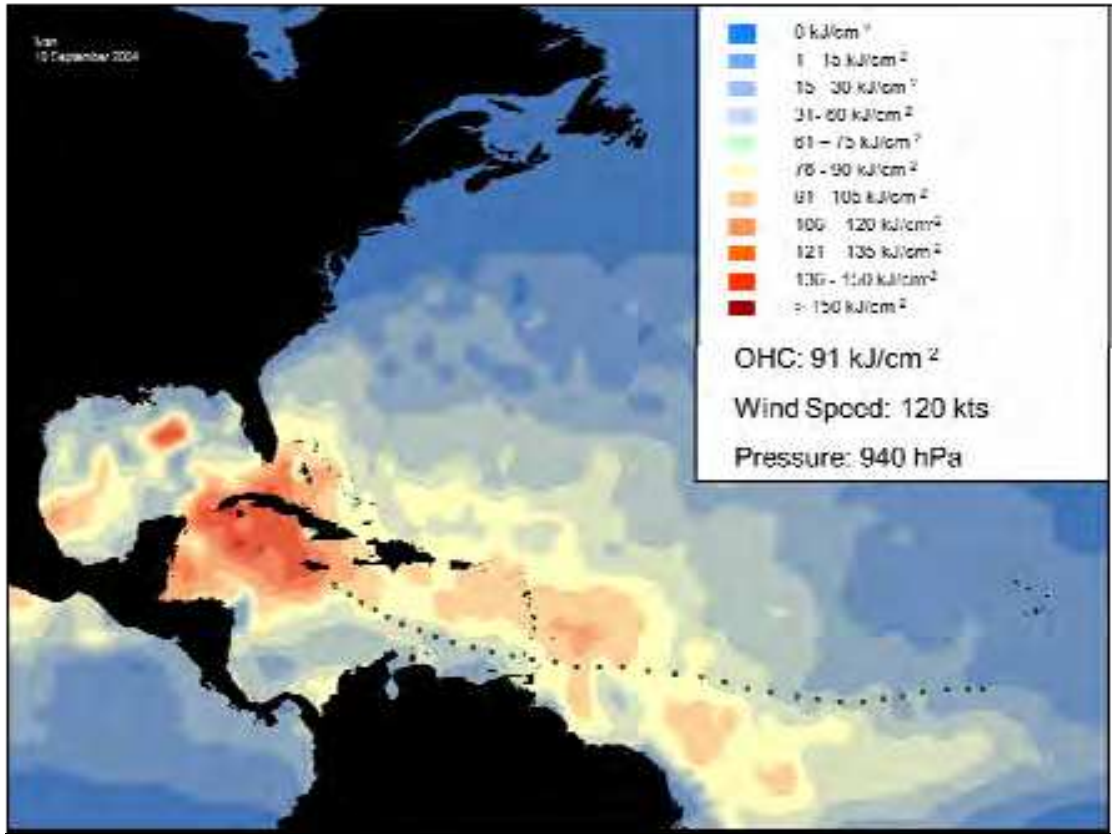

Fig. 19. Oceanic Heat Content of Hurricane Ivan, September 10, 2005 at 1800 UTC. 


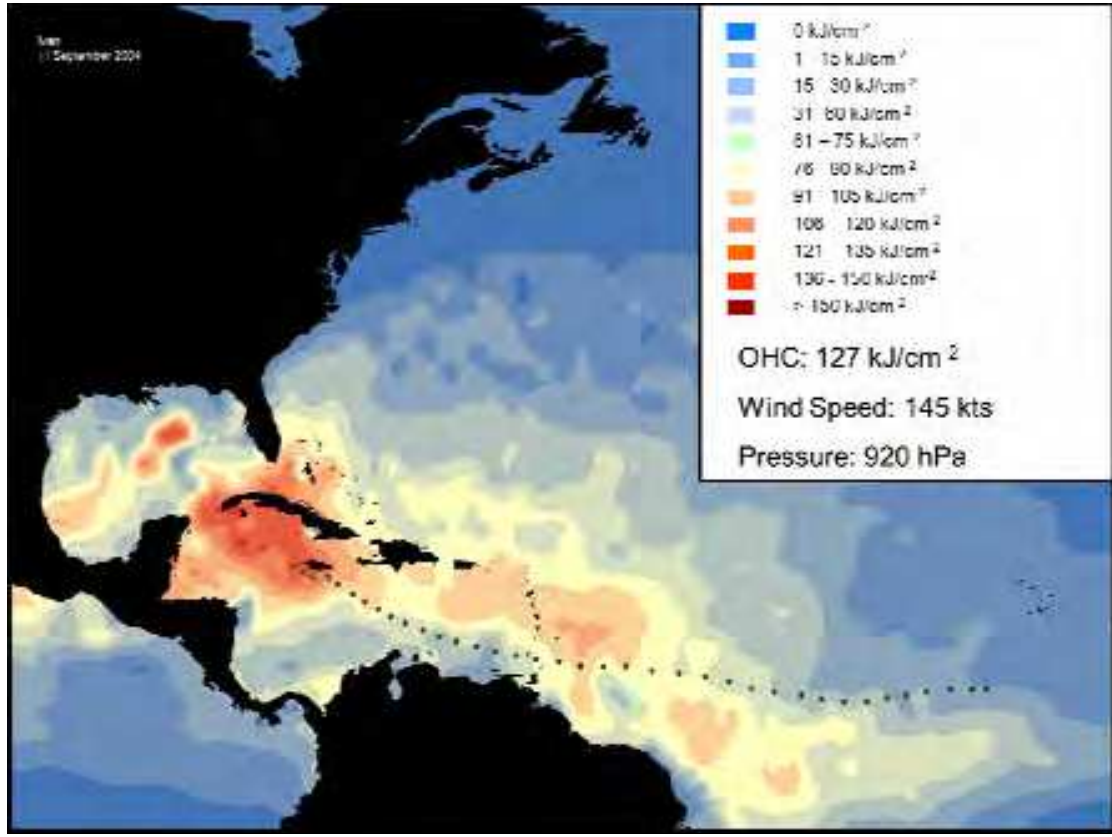

Fig. 20. Oceanic Heat Content of Hurricane Ivan, September 11, 2005 at 1800 UTC.

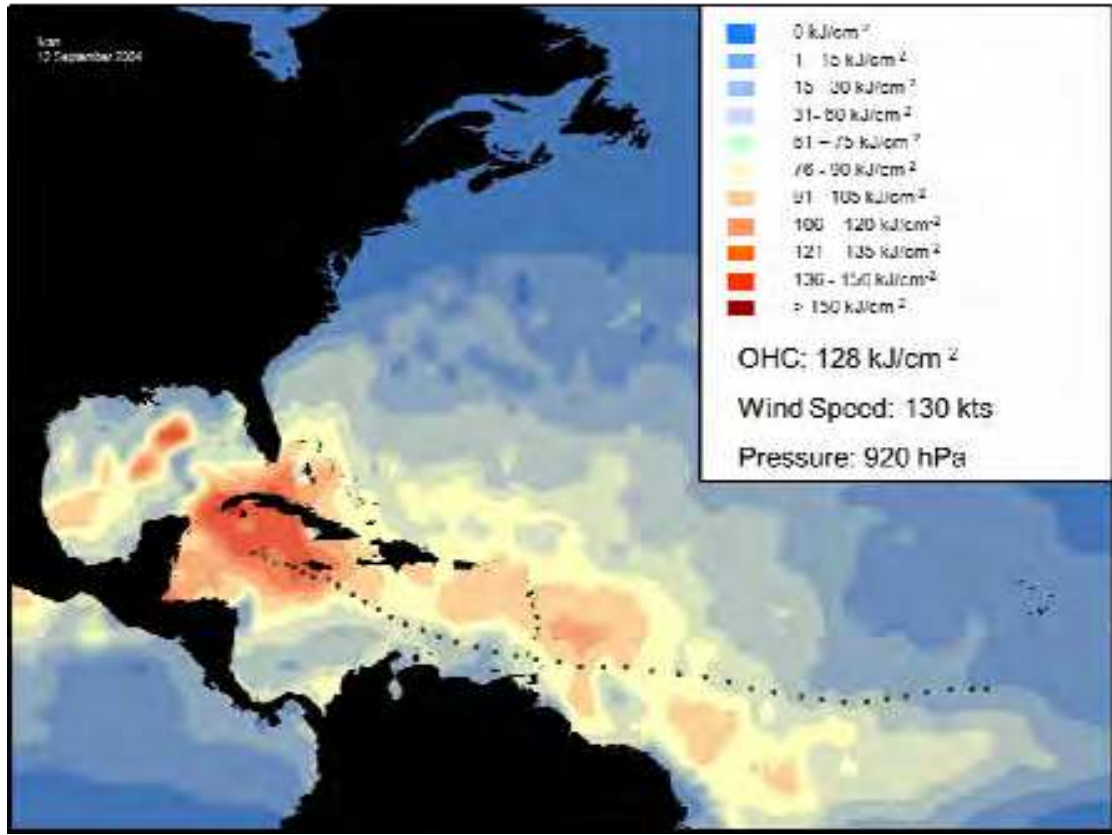

Fig. 21. Oceanic Heat Content of Hurricane Ivan, September 12, 2005 at 1800 UTC. 


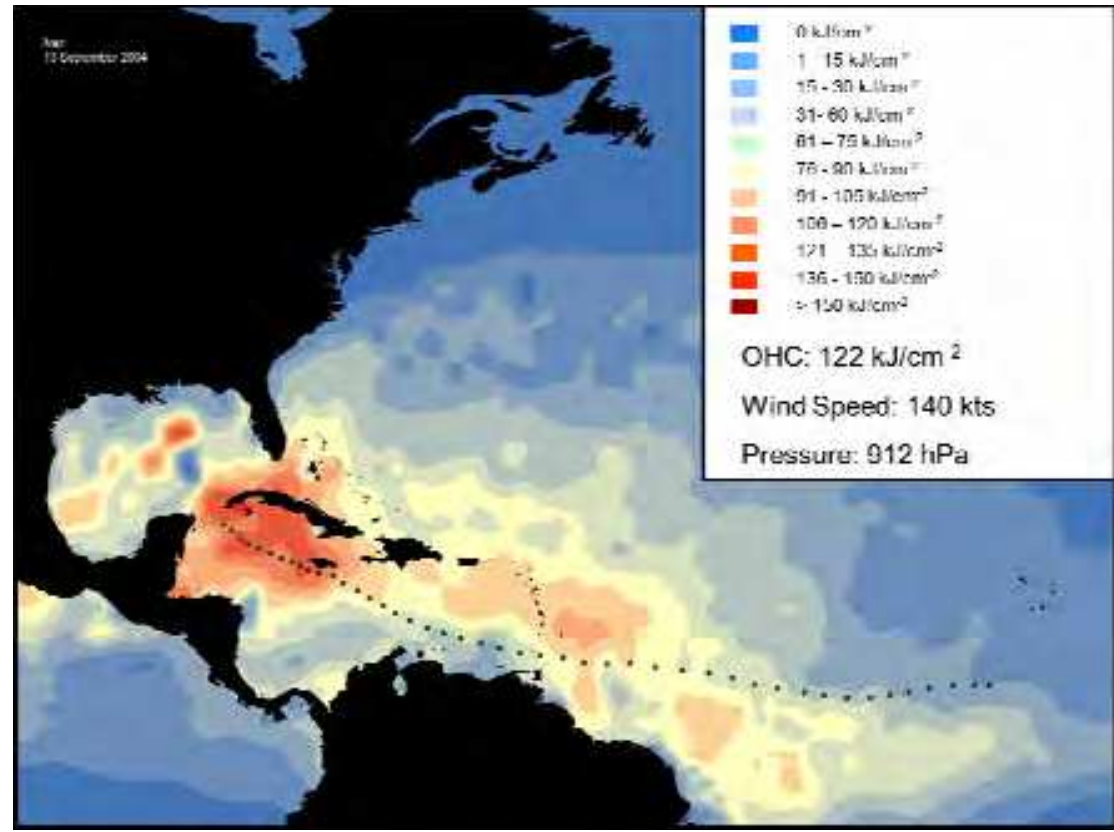

Fig. 22. Oceanic Heat Content of Hurricane Ivan, September 13, 2005 at 1800 UTC.

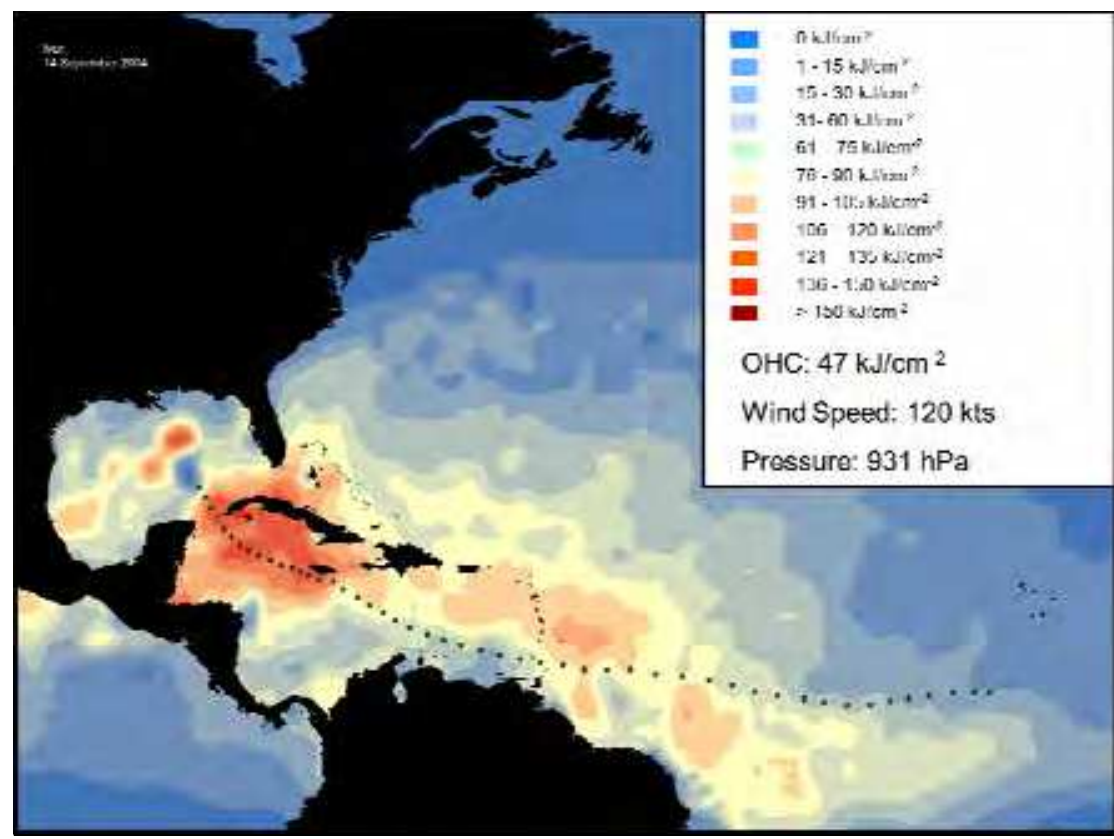

Fig. 23. Oceanic Heat Content of Hurricane Ivan, September 14, 2005 at 1800 UTC. 


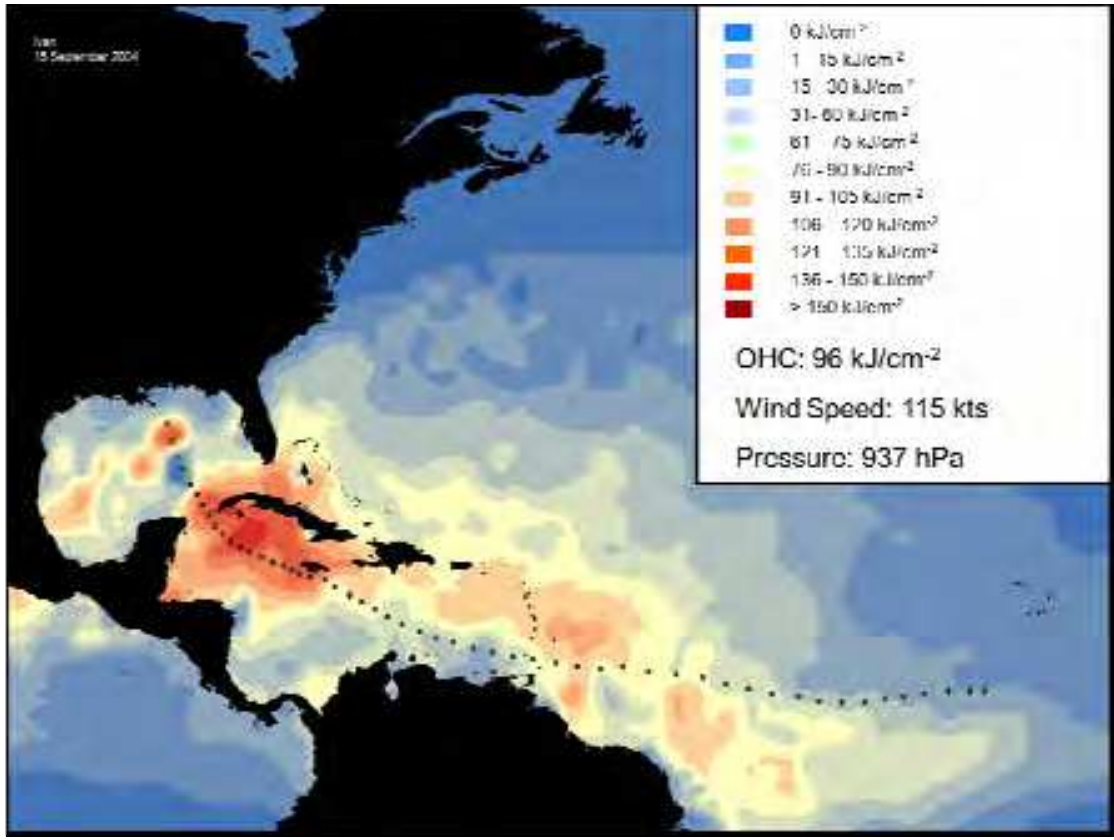

Fig. 24. Oceanic Heat Content of Hurricane Ivan, September 15, 2005 at 1800 UTC.

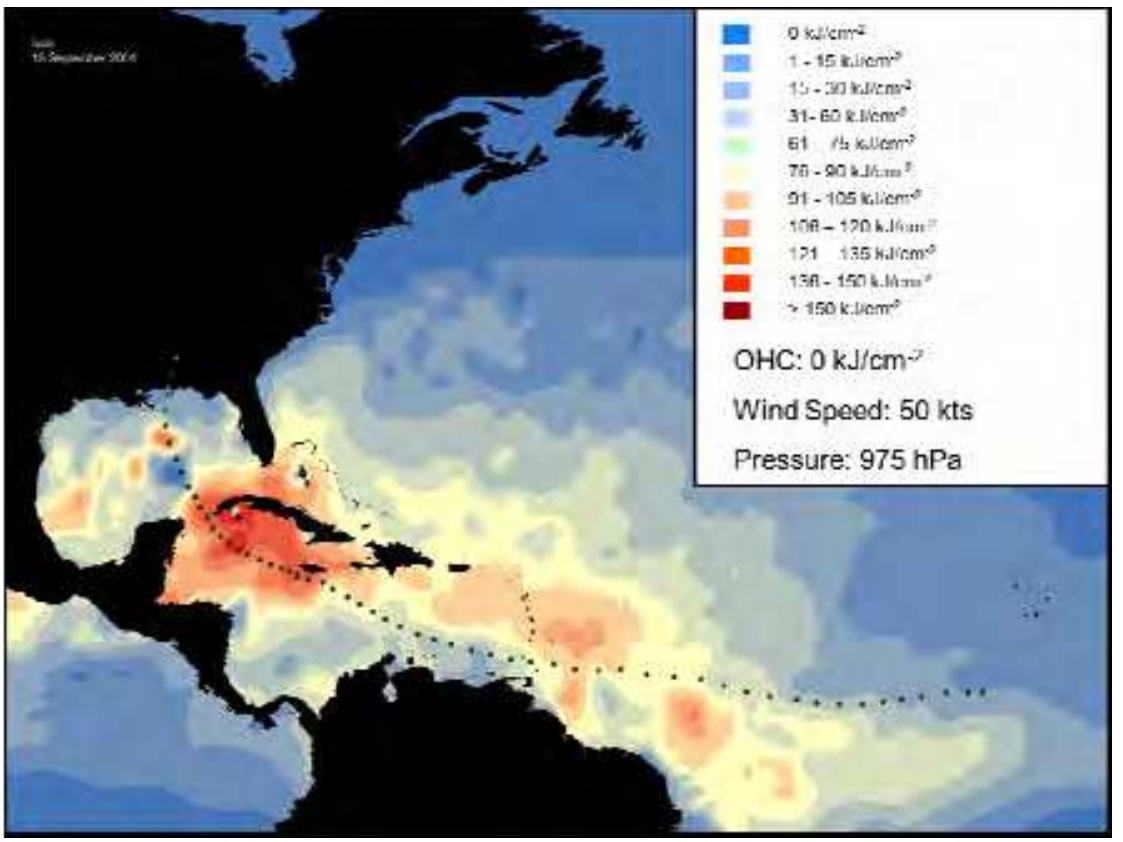

Fig. 25. Oceanic Heat Content of Hurricane Ivan, September 16, 2005 at 1800 UTC. 
hurricanes. However, the official intensity forecast from the National Hurricane Center (OFCL) did produce more accurate forecasts for Charley, Ivan, Jeanne, and Rita. It was noteworthy that this particular model produced much more accurate intensity forecasts for Katrina. This is likely due to the inclusion of $\mathrm{OHC}$ in the major hurricane strengthening model.

\begin{tabular}{|l|l|l|l|}
\hline Selected Storm & Average Error (kts) & OFCL error (kts) & SHF5 (kts) \\
\hline Hurricane Charley (2004) & 14.5 & 9.2 & 14.7 \\
\hline Hurricane Frances (2004) & 9.2 & 10.4 & 13.0 \\
\hline Hurricane Ivan (2004) & 11.9 & 11.7 & 16.5 \\
\hline Hurricane Jeanne (2004) & 13.6 & 8.8 & 14.1 \\
\hline Hurricane Katrina (2005) & 10.8 & 17.8 & 28.0 \\
\hline Hurricane Rita (2005) & 18.3 & 16.2 & 28.1 \\
\hline Hurricane Wilma (2005) & 17.5 & 18.2 & 19.0 \\
\hline
\end{tabular}

Table 10. 24-h average error for selected tropical cyclones by the statistical intensity model

\section{Conclusion}

This study showed the importance of $\mathrm{OHC}$ in the role of rapid intensification of Atlantic Hurricanes. By utilizing a different type of statistical-dynamic model which applies a regression model in a particular stage during the life of a hurricane, rather than applying one uniform equation, significant variables can be identified. OHC was identified as such during weakening and strengthening cases for major hurricanes. OHC was a better discriminating variable than SST for minor and major hurricanes however SST was better for tropical storms. This is likely due to the fact that minor and major hurricanes churn deep water and need to extract the energy required to maintain their substantial strength.

By including $\mathrm{OHC}$ in the model and applying it during the weakening and strengthening cases for major hurricanes, it produced more accurate 24-h forecasts. The model was able to produce more accurate forecasts than SHIFOR5 for seven major hurricanes during 20042005, most notably Hurricane Katrina. However, it still did not produce better forecasts than all of the official National Hurricane Center forecasts.

More research needs to be conducted regarding the variables used in the equations to improve the accuracy of the regression equations and DFA classification. Additional forecast intervals need to be investigated besides short-term 24-h forecasts. In the future, other tropical cyclone basins also need to be examined to see how $\mathrm{OHC}$ and other parameters perhaps vary and influence hurricane intensification.

\section{References}

Anthes, R. A., \& Chang, S. W., (1978). Response of the Hurricane Boundary Layer to Changes of Sea Surface Temperature in a Numerical Model. el Atmos. Sci., 35, (1240-1255)

DeMaria M., \& Kaplan J., (1999). An Updated Statistical Hurricane Intensity Prediction Scheme (SHIPS) for the Atlantic and Eastern North Pacific Basins. Wea. Forecasting, $14,(326-337)$ 
DeMaria M., Mainelli M., Shay, L. K., Knaff, J. A., \& Kaplan J. (2005). Further Improvements to the Statistical Hurricane Intensity Prediction Scheme (SHIPS). Wea. Forecasting, 20, (531-543)

Franklin J. L, (2005). 2004 National Hurricane Center Forecast Verification Report. National Hurricane Center, NOAA/NWS/NCEP/Tropical Prediction Center, (1-52)

Franklin J. L, (2006). 2005 National Hurricane Center Forecast Verification Report. National Hurricane Center, NOAA/NWS/NCEP/Tropical Prediction Center, (1-52)

Goni, G., Kamholz, S., Garzoli, S., \&Olson, D., (1996). Dynamics of the Brazil-Malvinas Confluence Based on Inverted Echo Sounders and Altimetry, J. Geophys. Res., 101(C7), (16,273-16,289)

Gray, W, M., (1968). Global View of the Origin of Tropical Disturbances and Storms. Mon. Wea. Rev., 96, (669-700)

Kalnay, E., and Coauthors, (1996). The NCEP/NCAR 40-Year Reanalysis Project. Bull. Amer. Meteor. Soc., 77, (437-471)

Law, K. T., \& Hobgood, J. S, (2007). A Statistical Model to Forecast Short-Term Atlantic Hurricane Intensity. Wea. Forecasting., 22, (967-980)

Leipper, D., \& Volgenau, D., (1972). Hurricane Heat Potential of the Gulf of Mexico. d Phys. Oceanogr., 2, (218-224)

Mainelli, M., DeMaria, M, Shay, L., \& Goni, G., (2008). Application of Oceanic Heat Content Estimation to Operational Forecasting of Recent Atlantic Category 5 Hurricanes. Wea. Forecasting, 23, (3-16)

McDougall, T., J., (2003). Potential Enthalpy: A Conservative Oceanic Variable for Evaluating Heat Content and Heat Fluxes. \& Phys. Oceanogr., 33, (945-963)

Palmer, M. D., \& Haines, K., (2009). Estimating Oceanic Heat Content Change Using Isotherms. el Climate, 22, (4953-4969)

Reynolds R. W., (1988). A real-time global sea surface temperature analysis. I Climate, 1, 75-86.

Reynolds, R. W., \& Marsico, D. C., (1993). An improved real-time global seas surface temperature analysis. Il Climate, 6, (114-119)

Reynolds, R. W., \& Smith, T. M., (1994). Improved global sea surface temperature analyses. cl Climate, 7, (929-948)

Schade, L. K., \& Emmanuel, K. A., (1999). The Ocean's Effect on the Intensity of Tropical Cyclones: Results from a Simple Coupled Atmosphere-Ocean Model. I Atmos. Sci., $56,(642-651)$

Shay L. K., Goni G. J., \& Black P. G., (2000). Effect of a Warm Ocean Ring on Hurricane Opal. Mon Wea. Rev., 128, (1366-1383)

Shay, L. K., \& Brewster, J. K., (2010). Oceanic Heat Content Variability in the Eastern Pacific Ocean for Hurricane Intensity Forecasting. Mon. Wea. Rev., 138, (2110-2131)

Wada, A., \& Usui, N., (2007). Importance of Tropical Cyclone Heat Potential for Tropical Cyclone Intensification in the Western North Pacific. If of Oceanography, 63, 3, $(427-447)$

Zebiak, S. E., (1989). Oceanic Heat Content Variability and El Niño Cycles. el Phys. Oceanogr., $19,(475-486)$ 


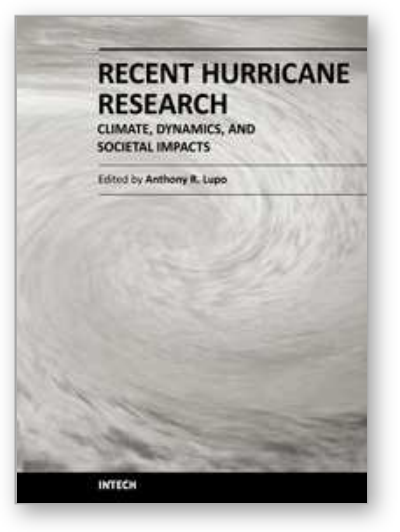

\author{
Recent Hurricane Research - Climate, Dynamics, and Societal \\ Impacts \\ Edited by Prof. Anthony Lupo
}

ISBN 978-953-307-238-8

Hard cover, 616 pages

Publisher InTech

Published online 19, April, 2011

Published in print edition April, 2011

This book represents recent research on tropical cyclones and their impact, and a wide range of topics are covered. An updated global climatology is presented, including the global occurrence of tropical cyclones and the terrestrial factors that may contribute to the variability and long-term trends in their occurrence. Research also examines long term trends in tropical cyclone occurrences and intensity as related to solar activity, while other research discusses the impact climate change may have on these storms. The dynamics and structure of tropical cyclones are studied, with traditional diagnostics employed to examine these as well as more modern approaches in examining their thermodynamics. The book aptly demonstrates how new research into short-range forecasting of tropical cyclone tracks and intensities using satellite information has led to significant improvements. In looking at societal and ecological risks, and damage assessment, authors investigate the use of technology for anticipating, and later evaluating, the amount of damage that is done to human society, watersheds, and forests by land-falling storms. The economic and ecological vulnerability of coastal regions are also studied and are supported by case studies which examine the potential hazards related to the evacuation of populated areas, including medical facilities. These studies provide decision makers with a potential basis for developing improved evacuation techniques.

\title{
How to reference
}

In order to correctly reference this scholarly work, feel free to copy and paste the following:

Kevin Law (2011). The Impact of Oceanic Heat Content on the Rapid Intensification of Atlantic Hurricanes, Recent Hurricane Research - Climate, Dynamics, and Societal Impacts, Prof. Anthony Lupo (Ed.), ISBN: 978953-307-238-8, InTech, Available from: http://www.intechopen.com/books/recent-hurricane-research-climatedynamics-and-societal-impacts/the-impact-of-oceanic-heat-content-on-the-rapid-intensification-of-atlantichurricanes

\section{INTECH}

open science | open minds

\section{InTech Europe}

University Campus STeP Ri

Slavka Krautzeka 83/A

51000 Rijeka, Croatia

Phone: +385 (51) 770447

Fax: +385 (51) 686166

\section{InTech China}

Unit 405, Office Block, Hotel Equatorial Shanghai

No.65, Yan An Road (West), Shanghai, 200040, China 中国上海市延安西路65号上海国际贵都大饭店办公楼 405 单元

Phone: +86-21-62489820

Fax: +86-21-62489821 
www.intechopen.com 
(C) 2011 The Author(s). Licensee IntechOpen. This chapter is distributed under the terms of the Creative Commons Attribution-NonCommercialShareAlike-3.0 License, which permits use, distribution and reproduction for non-commercial purposes, provided the original is properly cited and derivative works building on this content are distributed under the same license. 